\title{
The Effect of KRX Halts on Overheated Short-selling Stocks
}

\author{
Woo Baik Lee ${ }^{* *}$, Professor, Korea National Open University
}

\begin{abstract}
$\langle$ Abstract $\rangle$
Korea Exchange (KRX) has adopted several measures to ease temporary overheating of short-selling stocks in the market since March 27, 2017. These measures aim to curb excessive volatility and unfair trade, promoting efficient price discovery. This study examines the effect of overheated short-selling halts using the sample data from these KRX measures during the period of September 2017 to October 2019. The major empirical results are: first, the drop in prices of overheated short-selling stocks on a downward trend slows significantly after KRX announcement. Moreover, the stock price rise on the triggering day shows no additional increase in the period after the trigger. Second, for the stocks so triggered, the volatility in the period after the halt announcement shows no significant difference from the pre-halt period. This can be attributed to the resolution of the information asymmetry by calling investors' attention to overheated short-selling. Third, the ratio of short-selling to trading after halt suggests no statistically significant difference from the period before the trigger. These results imply that the measures to ease overheated short sale of stocks in KRX are effective in controlling excessive temporary volatility and unfair trading,
\end{abstract}

Keywords: Short-selling; Price Discovery; Volatility; Information Asymmetry; Event Study JEL Classification: G14, G18

\footnotetext{
* This research was supported by Research Grant Program the Korean Securities Association and FnGuide in 2019.

** Corresponding Author. Address: Korea National Open University, 86 Daehak-ro, Jongro-gu, Seoul, Korea 03087, E-mail: datalover@knou.ac.kr; Tel: +82-2-3668-4629; Fax: +82-2-3673-0562.
}

Received: June 9, 2020; Revised: October 15, 2020; Accepted: October 16, 2020 


\title{
공매도 과열종목 지정제도의 실효성 분석*
}

\author{
이 우 백 (한국방송통신대학교 교수)**
}

\begin{abstract}
공매도 과열종목 지정제도는 비정상적으로 공매도가 급증하고 가격이 급락한 종목을 공매도 과열종목 으로 지정하여 단기과열 현상을 완화하고 해당 종목에 대해 투자자의 주의를 환기시키기 위한 시장경보제도의 일종이다. 2017년 9월부터 2019년 10월까지의 기간동안 공매도 과열종목으로 지정된 표본을 대상으로 제도의 실효성을 평가한 결과를 요약하면 다음과 같다. 첫째, 시장과 지정유형별로 과열 종목 지정 전 기간의 주가변동에 대해 지정 후 기간에 후속하는 추가적인 주가급변은 없는 것으로 분석되었다. 즉, 주가가 급락하여 과열 종목으로 지정된 유형은 지정 후 기간에 하락하는 추세가 현저히 제한되었으며, 지정일에 주가가 상승한 종목의 유형의 표본들에서는 지정 후 기간에도 추가적 상승 없이 진정되는 행태를 보였다. 이는 공매도 과열거래에 내포될 가능성이 있는 투기거래에 대한 주의를 환기하여 추가주가 급락과 추종 공매도를 억제하여 급격한 가격변동을 완화하는 기능을 수행하는 과열 종목 지정 제도의 본질적 목적에 부합한다고 평가된다. 둘째, 주가 변동성도 지정일에만 급등했으나, 지정 후 기간의 변동성은 지정 전 기간의 수치와 유의적인 차이를 발견할 수 없었다. 이는 공매도의 과열종목 지정이라는 정보 내용이 시장의 투자자들에게 공매도 과열에 대한 주의를 환기시켜 정보 비대칭을 해소한 결과로 해석할 수 있다. 셋째, 공매도 거래 행태를 측정하는 지표인 공매도거래비율의 과열 종목 지정 후의 수치는 지정 전 기간과 통계적으로 유의적인 차이는 발견되지 않거나, 감소하는 결과가 도출되어 추종 공매도를 제한했음을 시사한다. 이같은 실증분석 결과는 현행 공매도 과열종목 지정제도는 투자자의 주의를 환기하여 시장상황을 판단할 수 있는 기회를 부여하며, 주가변동을 진정시키는 시장 건전화 기능에 대한 정보 효과가 존재함을 시사한다.
\end{abstract}

핵심 단어 : 공매도, 가격발견, 정보비대칭, 변동성, 사건연구

JEL 분류기호: G14, G18

\footnotetext{
* 본 연구는 2019년 한국증권학회-FnGuide 연구지원사업으로 수행되었으며, FnGuide 자료를 사용 하였습니다. 본 논문의 개선을 위해 유익한 조언을 해주신 익명의 심사자께 깊이 감사드립니다.

** 연락담당 저자. 주소: 서울특별시 종로구 대학로 86 한국방송통신대학교 사회과학대학 경영학과, 03087; E-mail: datalover@knou.ac.kr; Tel: 02-3668-4629; Fax: 02-3673-0562.
} 


\section{1. 서론}

주식시장에 새로운 정보가 유입되어 가격에 즉시 적절하게 반영되기 위해서는 유동성이 뒷받침되어야 한다. 공매도(short-sale)는 특정 종목의 주가하락을 예상하지만, 해당 종목의 주식을 보유하지 못한 투자자에게 주식을 대여하여 매도수요를 충족시켜 유동성을 창출한다. 이러한 공매도의 가수요 창출의 순기능에도 불구하고, 기존 주주가 보유한 주식의 가치가 하락하면 공매도 거래자만 이익을 독점하기 때문에 국내 일반 투자자들에게는 부정적으로 인식되고 있으며 금융위기가 발생하는 경우 긴급히 규제가 적용되는 대상이기도 하다.

특히 2008년 3분기에 미국발 금융위기 이후 금융시장이 붕괴될 수 있다는 우려가 확산되어, 전세계 각국 금융시장에서 공매도 규제 강화 정책들이 시행되었던 역사적 경험이 있다.1) 우리나라도 2008년 10월 1일부터 2009년 5월 31일까지 유가증권시장 및 코스닥시장 전체 상장종목에 대한 공매도를 한시적으로 금지했었으며, 유럽 재정위기 당시인 2011년 8월 10일부터 11 월 9일까지 3개월간 전종목 공매도가 금지 조치가 시행되었다. 한국 주식시장에서는 과거에도 무차입 공매도(naked short sales)는 원칙적으로 금지되었지만, 이같은 조치는 상장된 전체 종목에 대해 차입 공매도(covered short sales)까지 전면 금지한다는 점에서 정책적 의미를 가진다. 이같이 상장종목 전체에 대해 무차입 공매도는 물론 차입 공매도까지 금지한 것은 다른 나라에서 실시되었던 어떠한 제한 조치보다 강력한 것이었다. 최근 2020년 1 분기부터 확산된 코로나19로 인한 주가 하락에 대한 조치로 우리나라 금융당국은 3월 15일부터 9월 15 일까지 6 개월간 전체 종목에 대해 금지를 시행하고 있으며 이는 유럽 재정위기 이후 10 년만에 이루어진 강한 공매도 규제이다.

금융당국은 2008년 10월에 제정된 공매도 제한 조치 근거 이후 2020년 3월까지 7차례 추가적인 공매도 규제를 시행했음에도 불구하고, 규제 적용의 실효성에 관한 체계적 평가는 아직 미흡한 상황이다.2) 본 연구는 금융당국이 시행한 공매도 규제 중에서 한국거래소가 2017년 3월에 도입하고 그 해 9월부터 변경하여 운영하고 있는 '공매도 과열종목 지정제도'를 사례로 선정하여 개별 종목 수준의 공매도 규제의 실효성에 대해 검증한다.

본 연구의 분석대상인 '공매도 과열종목 지정제도'는 비정상적으로 공매도가 급증하고 가격이 급락한 종목에 대해 거래일 장종료 후 ‘공매도 과열종목'으로 지정하고, 다음 매매거래일 하루동안 공매도 거래를 금지하여 단기과열 현상을 완화하고 해당 종목에 대해 투자자의 주의를 환기시키기

1) 미국 SEC는 2008년 7월 21일부터 29일간 19개 대형 금융주에 대하여 무차입 공매도(naked short sale)을 금지했고, 2008년 9월 19일부터 10월 2일까지는 한시적으로 799 개 금융주에 대하여 차입 공매도를 포함한 모든 유형의 공매도를 금지시켰다. 영국 FSA도 2008년 9월 18일부터 2009년 1월 16 일까지 금융주에 대한 추가적인 순 숏 포지션 확대(net short position)를 금지했고, 독일도 2008년 9월 20일부터 12월 31 일까지 11 개 금융주에 대하여 공매도를 금지시켰다.

2) 2008년 10월 이후 공매도 규제 내용은 다음과 같다. 2009년 3월: 공매도 사전·사후관리 체계 강화, 2011년 8월: 전체 종목 공매도 금지, 2012년 8월: 공매도잔고 보고제도 도입, 2012년 10월: 공매도 사후관리 대상 확대, 2016년 6월: 공매도잔고 보고제도 개선 및 공시제도 도입, 2017년 3월: 공매도 과열종목 지정제도 도입과 공매도 규제 위반자 제재 강화, 2020년 3월: 전체 종목 공매도 금지 
The Effect of KRX Halts on Overheated Short-selling Stocks

위한 시장경보제도(market warning system)의 일종이다. 2017년 3월 27일에 최초로 시행된 제도의 결과에서는 공매도 과열종목으로 지정된 빈도가 극히 낮은 것으로 나타나 2017년 9월 25일부터는 과열 종목 적출 기준이 기존보다 완화된 제도가 적용되고 있다.3) 본 연구는 2017년 9월 25일부터 변경되어 시행되고 있는 공매도 과열종목 지정제도의 효과를 실증적으로 분석한다.

공매도에 대한 국내외 선행연구들의 주제는 공매도 거래자가 정보거래자(informed trader) 인지 여부 및 공매도와 시장효율성(market efficiency)간의 관계가 큰 줄기를 이루고 있으며, 글로벌 금융위기 이후에는 공매도 규제 강화에 따라 공매도가 시장에 미치는 영향에 대한 연구가 활발하게 진행되었다. 2008년 공매도 금지나 제한 조치를 전후하여 시장의 질적(market quality) 변화를 분석한 다수의 연구들은 대체로 공매도 규제가 시장의 가격발견기능을 저해하고 유동성에 부정적 영향을 초래함을 보였다. Saffi and Sigurdsson(2010)은 2005년부터 2008년까지 26 개국의 공매도와 가격 효율성간의 관계를 분석한 결과에서 공매도 제약이 높은 주식은 가격 효율성이 낮으며, 공매도 제약이 완화되어도 가격 변동성이 증가하거나 극단적인 음의 수익실현과는 관련이 없음을 제시했다. Boehmer et al.(2013)은 2008년에 단행된 미국의 공매도 금지가 대형주의 주가 변동에는 영향을 미치지 못한 반면, 소형주는 시장의 질적 수준에서 심각한 타격을 받았다고 보고한다. Kolasinski et al.(2013)은 2008년 미국의 공매도 규제로 인해 오히려 정보를 가진 거래자들이 공매도 비중을 활성화한 결과를 초래했다고 설명한다. Battalio and Schultz(2011)도 2008년 공매도 규제 기간동안 공매도가 금지된 주식의 옵션가격의 호가스프 레드가 증가했으며, 옵션으로 복제된 합성주식의 가격은 실제 주가보다 저평가되는 현상을 제시했다. Grundy et al.(2012)도 2008년 공매도 규제 기간동안 공매도가 금지된 주식의 옵션의 거래량이 급감했으며, 풋-콜 패리티 경계를 위반하는 빈도가 증가하여 파생상품시장의 질에 부정적 영향을 미쳤다는 결과를 발견했다. Marsh and Payne(2012)는 2008년 영국주식시장의 금융주에 대해 시행된 공매도 금지가 유동성 급감을 초래했으며, 이로 인해 시장미시구조 질적 측면에 부정적 영향을 미쳤다고 보고한다. Beber and Pagano(2013)도 2007년부터 2009년까지 기간동안 세계 각국에서 조치한 공매도 규제로 인해 주로 소형주의 유동성이 저해되었으며, 주식 침체기에 가격발견이 지체되는 부정적 영향이 크다고 주장했다.

이와 같이 국외에서 수행된 다수의 연구들의 결론은 일관적으로 공매도 규제의 부정적 효과에 수렴하는 반면, 공매도 규제를 다룬 국내 연구는 공매도 연구 분야에서 상대적으로 소수에 국한 되어 있다. Choe and Lee(2012)는 공매도 규제 시기에 시장 전체의 유동성이 저하되고 일중변동성이 증가했으며, $\mathrm{Kim}$ and $\mathrm{Seo}(2015)$ 도 국내 주식시장에서 공매도 제약이 강한 경우 이익예측치의 의견불일치로 인해 주가의 과대평가를 야기시켰다는 결론을 주장하여 공매도 금지가 시장에 미친 부정적 효과를 제시하고 있다.

이상의 공매도 규제와 관련된 선행연구들은 글로벌 금융위기 당시 개별 국가에서 시행되었던 시장 전체 종목에 대한 한시적 공매도 거래 중단이 미치는 영향에 초점을 두고 수행되었으나

3) 2017년 3월 27일에 제도 시행 이후 4개월간 공매도 과열 상태로 지정된 종목수는 총 11 건(유가증권시장 5 회, 코스닥 6 회)으로 집계되었다. 
한국증권학회지 제49권 5호 (2020)

개별 종목 수준에서 공매도 규제 제도의 실효성을 분석한 논문은 없다. 개별 종목 수준에서의 정보비대칭은 투자자간 사적정보(private information)의 보유 여부 또는 정보 분석 능력의 차이로 발생한다. 공매도가 과도히 증가한 개별 종목의 공매도 거래를 일정시간 동안 중지시켜 투자자들은 진정한 가격을 평가할 수 있는 시간을 부여하는 것은 투자자간 정보비대칭의 확대를 억제하고 가격발견의 효율성을 확보하는 순기능을 수행할 수 있다. 하지만 공매도가 중지된다면 정보가 가격에 반영되는 것을 지연시켜 오히려 비효율적인 가격발견을 초래할 가능성도 있다. 즉, 공매도 중지가 시장의 정보흐름을 방해하고 새로운 정보를 반영하는 가격발견 기능을 지연시키는 역할을 한다면 오히려 정보비대칭을 증폭시키는 역기능도 있을 수 있다. 국내에서 개별종목 매매의 과열 상태를 완화하기 위한 중단 장치 기능의 실효성을 분석한 연구로는 Lee and Park(2016)이 있다. 그러나 공매도만을 대상으로 중단 장치의 실효성을 검증한 연구는 아직까지 전무한 상황으로 볼 때, 본 연구는 공매도과열 완화 장치에 관한 최초의 학술적 연구로서 제도 운영에 관한 정책적 검토를 통해 의미있는 시사점을 제공한다는 점에서 차별화된다. 본 연구는 현행 공매도 과열종목 지정제도가 시행된 후의 기간을 분석 대상으로 하므로, 과열종목 지정제도가 시행되기 전 기간을 대상으로 분석한 $\mathrm{Kang}(2017)$ 의 연구가 가진 한계점과 차별화된 결론을 도출한다.

또한 본 연구의 실증결과는 현행 공매도 과열종목 지정제도가 금융당국에서 주시하고 있는 불공정거래에 해당하는 공매도 행위를 사전에 적출할 수 있는 도구로 활용될 수 있다. 공매도를 이용한 불공정거래 등 시장질서 교란행위를 사전에 적발하여 차단하는 것은 실질적으로 용이하지 않다. 현행 공매도 과열종목 지정제도가 투자자들의 공매도에 대한 신뢰를 제고하고 공매도를 악용한 투자세력을 억제하는 효과를 제고하기 위해서는 지정된 종목의 실제 공매도 과열 원인을 규명해야 한다. 따라서 이 연구의 결과를 통해 공매도를 이용한 불공정거래를 방지할 구체적 제도를 도입할 수 있는 후속 조치에 대한 개선방안을 제공할 수 있을 것이다.

본 연구에서 2017년 9월부터 2019년 10월까지의 기간동안 과열종목으로 지정된 표본을 대상으로 실증연구를 수행한 결과를 요약하면 다음과 같다. 첫째, 시장과 지정유형별로 과열 종목 지정 전 기간의 주가변동에 대해 지정 후 기간에 후속하는 추가적인 주가급변은 없는 것으로 분석되었다. 즉, 주가가 급락하여 과열 종목으로 지정된 유형은 지정 후 기간에 하락하는 추세가 현저히 제한되었으며, 지정일에 주가가 상승한 종목의 유형의 표본들에서는 지정 후 기간에도 추가적 상승 없이 진정되는 행태를 보였다. 이는 공매도 과열거래에 내포될 가능성이 있는 투기거래에 대한 주의를 환기하여 추가주가 급락과 추종 공매도를 억제하여 급격한 가격변동을 완화하는 기능을 수행하는 과열종목 지정제도의 본질적 목적에 부합한다고 평가된다. 둘째, 주가 변동성도 지정일에만 급등했으나, 지정 후 기간의 변동성은 지정 전 기간의 수치와 유의적인 차이를 발견할 수 없었다. 이는 공매도의 과열종목 지정이라는 정보 내용이 시장의 투자자들에게 공매도 과열에 대한 주의를 환기시켜 정보비대칭을 완화한 결과로 해석할 수 있다. 셋째, 공매도 거래 행태를 측정하는 지표인 공매도거래비율의 과열종목 지정 후의 수치는 지정 전 기간과 통계적으로 유의적인 차이는 발견되지 않거나, 감소하는 결과가 도출되어 추세를 추종하는 공매도를 제한했음을 시사한다. 이같은 실증분석 결과는 현행 공매도 과열종목 지정 
The Effect of KRX Halts on Overheated Short-selling Stocks

제도는 투자자의 주의를 환기하여 시장상황을 판단할 수 있는 기회를 부여하며, 주가변동을 진정시키는 시장 건전화 기능에 대한 정보 효과가 존재함을 시사한다.

이하에서 전개될 논문의 구성은 다음과 같다. 제 2 장에서는 본 연구의 분석 대상인 공매도 과열종목 지정제도의 개요를 설명한다. 제 3장에서는 연구에 사용된 표본의 특성과 개별 종목 수준에서 과열종목 지정이 주가변동과 공매도 행태에 미치는 사후적 영향을 분석하고, 실효성을 평가한다. 마지막으로 제 4 장에서는 연구의 주요 결과와 시사점을 요약하고 향후 연구의 방향을 제시한다.

\section{2. 과열종목 지정제도 개정과 공매도 행태}

\section{1 과열종목 지정제도 개요4)}

과열종목 지정제도 시행 전까지 적용되었던 개별 종목 대상 공매도 규제는 공매도 잔고 보고와 잔고 공시 규정이 있었다. 공매도 잔고 보고는 공매도 잔고비율이 $0.01 \%$ 이상이면서 잔고평가액 1 억 원 이상이면 보고 의무가 발생하며, 공매도 잔고 공시는 공매도 잔고비율 $0.5 \%$ 이상이면 공시의무가 발생한다.5) 금융당국이 이 규제들에 후속하여 2017년 3월에 공매도 과열종목 지정제도를 도입한 취지는 크게 세 가지로 요약할 수 있다. 첫째, 공매도를 일시적으로 금지하여 주가하락 가속화를 방지하는 효과이다. 즉, 주가가 하락하는 과정에서 공매도로 인한 추가적 주가하락과 추종매매를 억제하여 급격한 가격변동을 완화할 것으로 예상할 수 있다. 둘째, 공매도를 이용한 불공정거래 행위를 사전에 차단하거나 그 영향을 경감시키는 것이다. 공매도 과열종목으로 지정되면 시장에 알려지므로 투자자가 주의를 환기하게 된다. 특히 정보에서 열위에 있는 개인투자자에게 공매도가 단기간 집중적으로 발생한 종목 정보를 제공하여 정보비대칭을 완화하는 효과를 기대할 수 있다.

과열종목 지정제도는 공매도 과열종목을 적시에 지정할 수 있도록 공매도 과열종목 지정기준을 변경하고, 공매도 과열종목으로 적출된 종목에 대해 현행과 같이 익일 공매도를 금지한다는 내용이다. 코스피 시장과 코스닥 및 코넥스 시장의 공매도 과열종목 지정기준을 2017년 3월에 신설된 1 차 기준과 2017년 9월에 변경된 2차 기준을 비교하면 <표 1 >의 내용과 같다. 변경 전 공매도 과열종목 기준은 공매도 비중, 공매도 증가율, 주가하락률 등이 복합된 기준으로 이 세 가지 기준에 모두 부합할 때 과열종목으로 지정되었다. 그 중 가장 기본이 되는 것은 주가하락률이다. 즉, 시장에 과도한 주가급락의 위험을 경고하기 위한 제도이기 때문에 공매도 비중이 높더라도 주가가 유의적으로 하락하지 않으면 지정대상이 되지 않으며, 당일 종가가 전일 종가대비 $5 \%$ 이상 하락한 종목에 한해 과열종목 지정 여부를 결정한다. 이는 유가증권시장과 코스닥에 공통적으로 적용된다. 당일 공매도 비중 요인은 유가증권시장에는 $20 \%$ 이상이며,

4) 본 절의 내용은 Kang (2017)과 Financial Services Commission, Financial Supervisory Service and Korea Exchange (2017)을 참고함.

5) 공매도 잔고비율은 상장주식수 대비 공매도 잔고수량이며, 보고의무 발생일로부터 3 영업일 오전 9 시까지 추가 거래가 없어도 일별로 보고의무 발생기준 이상을 유지하면 매일 공시의무가 발생한다. 
코스닥시장은 이보다 낮은 $15 \%$ 이상으로 차등적으로 적용되었다. 이 두 가지 지정기준에 추가 기준인 '공매도비중 증가율'이 적용되어 당일 공매도비중이 직전 40거래일의 공매도비중 평균의 2 배 이상인 거래일에는 해당 종목은 공매도 과열종목으로 지정되었다.6) 공매도 과열종목은 정규시장의 거래가 종료된 18시 이후에 지정되며, 다음날 1 일간 공매도가 금지된다.7) 즉, 다음날 $(\mathrm{t}+1)$ 공매도 거래가 금지되며 $(\mathrm{t}+2)$ 일에 공매도 제재가 해제되고 다시 거래가 허용된다. 공매도비중 증가율은 과거 40일간 공매도비중 평균치를 정상(normal) 공매도비중으로 간주할 경우 초과 공매도비중의 의미를 가진다.8)

〈표 1〉 공매도 과열종목 지정제도 내용

\begin{tabular}{|c|c|c|c|c|c|c|c|}
\hline 기간 & 시장 & 유형 & 당일 공매도 비중 & $\begin{array}{c}\text { 당일 } \\
\text { 주가하락률 }\end{array}$ & $\begin{array}{l}\text { 공매도 } \\
\text { 거래비중 } \\
\text { 증가율 }\end{array}$ & $\begin{array}{l}\text { 공매도 } \\
\text { 거래대금 } \\
\text { 증가율 }^{2)}\end{array}$ & $\begin{array}{l}\text { 공매도 } \\
\text { 비중 } \\
\text { 평균 }^{3)}\end{array}$ \\
\hline \multirow{2}{*}{$\begin{array}{l}\text { 변경 전 } \\
\text { (2017.3.27. } \\
\sim \\
\text { 2017.9.24.) }\end{array}$} & 유가증권 & 단일 & $20 \%$ 이상 & $5 \%$ 이상 & 2 배 이상 & - & - \\
\hline & 코스닥 & 단일 & $15 \%$ 이상 & $5 \%$ 이상 & 2 배 이상 & - & - \\
\hline \multirow[t]{4}{*}{$\begin{array}{l}\text { 변경 후 } \\
(2017.9 .25 . \\
\text { ) }\end{array}$} & 유가증권 & (1) & $\begin{array}{c}\operatorname{Max} \text { [전분기 코스피시장 } \\
\text { 공매도비중× } 3,20 \%] \\
-\end{array}$ & $\begin{array}{r}5 \% \text { 이상 } \\
10 \% \text { 미만 } \\
10 \% \text { 이상 }\end{array}$ & - & 6 배 이상 & - \\
\hline & $\begin{array}{l}\text { 코스닥 } \\
\text { 코넥스 }\end{array}$ & (1) & $\begin{array}{c}\operatorname{Max}[\text { 전분기 코스닥 } 150 \\
\text { 공매도비중×3, 20\%] }\end{array}$ & $\begin{array}{l}5 \% \text { 이상 } \\
10 \% \text { 미만 }\end{array}$ & - & 5 배 이상 & - \\
\hline & & (2) & - & $10 \%$ 이상 & & & - \\
\hline & & (3) & - & - & & & $\begin{array}{l}5 \% \text { 이상 } \\
\text { (코스닥) }\end{array}$ \\
\hline
\end{tabular}

주: 1) 직전 40 거래일 공매도비중 평균 $\times 2 \leqq$ 당일 공매도 비중.

2) 직전 40 거래일 공매도대금 평균 $\times$ 배수 $\leqq$ 당일 공매도대금.

3) 직전 40거래일 공매도비중 평균.

출처: 금융위원회, 금융감독원, 한국거래소, 『공매도 제도 개선 및 제재 강화 방안』, 2017.8.24. 한국거래소, 『공매도 과열종목 지정제도 개선안 시행 안내』, 2017.9.21.

6) 공매도비중은 일별 거래대금 대비 공매도 거래대금으로 측정한다.

7) 공매도 과열종목으로 지정되었다 하더라도, (1)주식시장 유동성공급자(LP) 호가, (2)주식시장 시장 조성자(MM) 호가, (3)증권상품(ETF·ETN·ELW) 유동성공급자(LP)의 헤지거래 호가, (4)파생상품 시장조성자 $(\mathrm{MM})$ 의 헤지거래 호가를 대상으로는 예외적으로 공매도가 허용된다. 유동성공급자와 시장조성자는 정책적 목적으로 인위적인 유동성을 공급할 의무가 있으며, 이러한 유동성 공급시 공매도 등을 통한 헤지거래가 필수적인 점 등을 고려하여 예외적으로 공매도 거래가 허용된다.

8) 이는 투자실무에서 일부 활용되고 있는 기술적지표인 거래량 이격도(volume disparity)의 개념을 적용한 것이다. 거래량 이격도는 당일의 주가를 과거의 이동평균거래량으로 나눈 값으로 거래량이 이동평균선을 중심으로 회귀하는 특성으로 매매신호를 포착하는 기법이다. 실무에서는 이격도가 일정 수준 이상의 수치를 초과하면 시장의 과열상황으로 판단한다. 
The Effect of KRX Halts on Overheated Short-selling Stocks

2017년 9월 25일에 개정된 2차 기준은 2017년 3월 1차 기준을 보완하여 주가하락률에 따라 유형이 분류되고, 코스닥시장에만 적용되는 새로운 기준이 신설되었다. 유가증권시장과 코스닥 시장에 공통으로 적용되는 유형 1과 유형 2에 따르면 5\% 이상 주가가 하락한 경우 선별 대상이 된다. 유형 1은 당일 주가 하락률이 $5 \%$ 이상 $10 \%$ 미만이며, 유형 2 는 당일 주가가 전일 대비 $10 \%$ 이상 하락한 종목으로 유형 1에 비해 추가적 주가하락 위험이 높은 종목으로 분류된다. 그러나 유형 1 은 아래에서 설명할 공매도비중 기준과 공매도 거래대금 증가율의 기준에도 부합해야 과열 종목으로 지정되는 반면, 유형 2 는 당일 공매도 비중과 관계없이 주가하락률 기준과 공매도 거래대금 증가율 기준에 공통으로 해당하면 과열 종목으로 지정된다.

변경된 당일 공매도비중 기준을 보면 유가증권시장 상장 종목은 직전 분기 코스피 전체 종목 공매도 비중의 3배수와 $20 \%$ 중 큰 수치의 이상이어야 하며, 코스닥시장과 코넥스시장 상장종목은 직전분기 코스닥 150 을 구성하는 종목들의 공매도 비중의 3 배수와 $20 \%$ 중 큰 수치의 이상이면 과열 종목 기준에 해당한다. 종전 기준은 공매도비중이 각각 $20 \%$ 와 $15 \%$ 로 고정된 상수인데 비해, 변경 기준은 과거 시장상황에 따른 공매도 규모변화를 반영하여 전분기 상황에 따라 정기적 변경이 가능한 것이 특징이다. 이는 주식시장에서 상승장이 이어질 경우 시장 전반의 공매도 물량이 감소할 수 있는데, 이러한 추세적 변화에 따른 공매도 변화를 반영하기 위한 계산방법이다. 변경된 기준에서는 공매도비중 증가율 대신 '공매도 거래대금 증가율'이 새로운 기준으로 도입되었다. 이는 공적 악재성 정보가 시장에 유입될 경우 통상적으로 공매도와 동반하여 실매도가 급증하므로 공매도비중 증가율 기준을 충족하기 어렵다는 문제점이 지적되었기 때문이다. 공매도 거래대금 증가율은 직전 40 거래일의 공매도 거래대금 대비 당일 공매도 거래대금의 배수로, 유가증권시장의 과열종목 기준은 6 배 이상이며 코스닥시장과 코넥스시장의 기준은 5 배 이상이다. 따라서 공매도가 총거래대금에 비하여 적은 종목일지라도 과거에 비하여 공매도가 일정 수준 이상으로 급증할 경우 공매도 과열종목으로 지정된다. 개정 기준에서 가장 큰 특징은 코스닥시장에 새로운 유형 3 인 신설되었다는 점이다. 유형 3 은 주가변동 기준과 공매도 비중 기준은 배제하고, 공매도 거래대금 증가율이 5 배 이상이며 직전 40 거래일 평균 공매도 비중이 $5 \%$ 이면 과열종목으로 지정된다. 따라서 당일 공매도 비중이 기준에 미치지 못하는 종목이라도, 과거 공매도 비중이 지속되고 당일 공매도가 일정 수준 이상으로 급증할 경우 공매도 과열종목으로 지정될 수 있다.

\section{2 지정제도 개정 전 · 후 기간의 공매도 행태}

$<$ 그림 1>의 패널 A에는 공매도 과열종목 지정제도 강화 전·후 주가지수와 공매도 행태를 제시한다. 공매도 과열종목 지정 제도가 최초로 도입된 2017년 3월 27일부터 과열종목 지정제도가 개정되기전 2017년 9월 24일까지의 기간(124거래일)인 제도 개정 전 기간과, 변경된 제도가 시행된 9월 25일부터 변경 전 기간과 동일한 거래일이 경과한 시점인 2018년 4월 2일까지의 기간의 주가지수를 보면 유가증권시장과 코스닥 모두 상승하는 추세였다. 유가증권시장의 코스피는 제도 개정 전 기간에 2,155.66에서 2,388.71까지 $10.81 \%$ 상승했으나, 제도 개정 후 기간의 증가율은 $2.68 \%$ 로 그 상승세가 둔화되었다. 반면, 코스닥지수는 제도 개정 전 기간의 
상승률은 $6.90 \%$ 였지만, 제도 개정 후에는 상승 속도가 가속화되어 그 증가율은 $35.16 \%$ 로 유가증권시장의 상승률보다 현저히 높았다.

패널 $\mathrm{B}$ 의 공매도금액과 패널 $\mathrm{C}$ 의 공매도거래비율에서는 유가증권시장과 코스닥시장간의 규모 차이가 제도 개정 전 기간 중반부터 좁혀짐이 관찰된다. 특히 패널 $\mathrm{A}$ 에서 코스닥지수의 고점 도달 직후 시점에 패널 $\mathrm{B}$ 와 패널 $\mathrm{C}$ 에서 공매도금액과 공매도비중이 급증한 행태가 관찰되는데, 이는 주가 하락 추세에 편승하여 수익을 추구하는 공매도 추종 거래자들로 인해 코스닥시장에서 공매도가 증가한 유인으로 작용한 것으로 추론할 수 있다.

〈그림 1〉 공매도 과열종목 지정 제도 변경 후 주가지수와 공매도 행태

패널 $\mathrm{A}$ : 주가지수

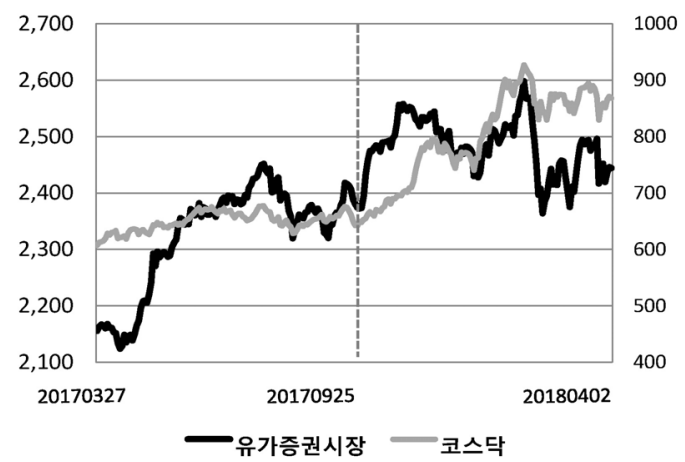

패널 C: 공매도거래비율

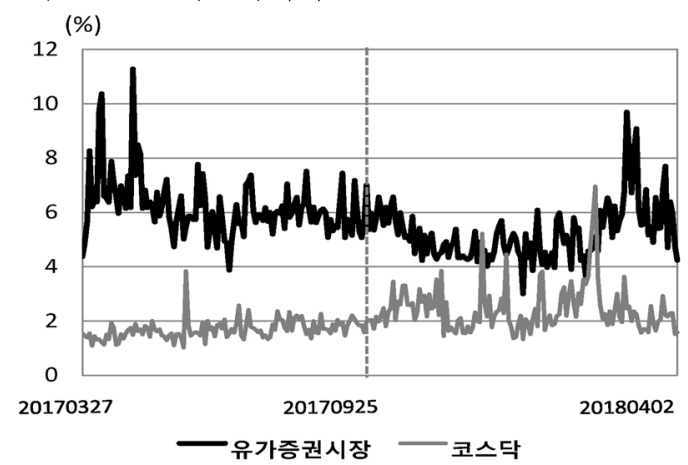

패널 B: 공매도금액

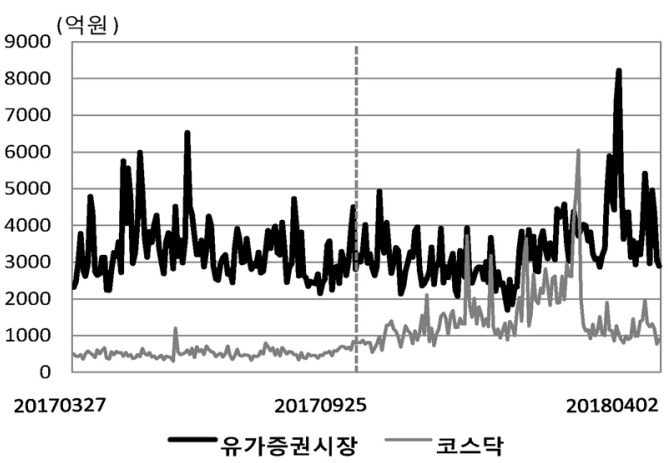

<표 2>에서는 공매도 과열종목 지정제도가 개정된 2017년 9월 25일을 기준으로 150 일 전·후 기간을 설정하여 제도 개정이 공매도 행태에 미친 효과를 통계적으로 평가한다. 유가증권시장에서 변경 전 150일 기간의 일평균 공매도비중은 $6.36 \%$ 에서 $5.30 \%$ 로 1.06 포인트 감소했으며, $1 \%$ 수준에서 통계적으로 유의적이다. 변경 후 일평균 공매도 거래량은 $9,498,000$ 주로 변경 전 거래량 $9,246,000$ 주에 대비하여 $2.73 \%$ 증가했으나, 이에 대한 통계적 유의성은 없었다. 그러나 변경 후 일평균 공매도 거래대금은 35,994백만 원으로 변경 전 거래대금 대비 $7.22 \%$ 로 증가하였으며 $\mathrm{t}$ 검정 결과에서 $5 \%$ 수준에서 유의적이다. 이렇게 일평균 공매도 거래대금이 증가했음에도 
The Effect of KRX Halts on Overheated Short-selling Stocks

불구하고, 공매도비중이 감소한 원인은 이 기간동안 공매도비중의 분모인 거래대금이 변경 전 기간 대비 $27.57 \%$ 증가하여 분자인 공매도 금액의 증가율을 대폭적으로 상회하기 때문이다.

코스닥시장에서는 제도 변경 후 모든 공매도 관련 지표들이 변경 전 기간의 수치에 비해 $1 \%$ 수준에서 유의적으로 증가했다. 공매도비중은 $0.70 \%$ 포인트 증가했으며, 거래량은 $3,016,000$ 주가 증가하여 유가증권시장의 증가폭과 증가율보다 높다. 코스닥시장의 제도 변경 전 일평균 공매도 거래대금은 526 백만 원으로 거래대금의 $1.57 \%$ 에 불과했으나, 제도 변경 후 1,503 백만 원으로 $186 \%$ 증가하여 동일기간 유가증권시장 공매도 규모의 $4.18 \%$ 을 차지한다. 따라서 제도 변경 전·후 장기간의 주가 변동 추세에 따른 공매도 거래 양태를 보면 제도 변경 후 기간에는 상대적으로 코스닥시장의 상승폭이 유가증권시장보다 높으며, 공매도 거래 활동도 유가증권시장의 공매도 거래 활동보다 높다는 것으로 요약할 수 있다.

〈표 2〉 공매도 과열종목 지정제도 변경 전·후 공매도 지표 비교 공매도 과열종목 지정제도가 변경된 2017년 9월 25일을 기준으로 150 거래일 전 기간과 150 거래일 후 기간의 공매도 관련 지표의 기간차이 검정결과이다. 표에 제시된 값은 일평균치이며, 괄호안의 값은 표준편차이다. ${ }^{*},{ }^{* *},{ }^{* * *}$ 는 각각 $10 \%, 5 \%, 1 \%$ 수준에서 유의적이다.

\begin{tabular}{|c|c|c|c|c|c|c|}
\hline \multirow{2}{*}{\multicolumn{2}{|c|}{ 공매도 통계 }} & \multirow{2}{*}{$\begin{array}{l}\text { 변경 전 기간 } \\
\text { (pre period) }\end{array}$} & \multirow{2}{*}{$\begin{array}{l}\text { 변경 후 기간 } \\
\text { (post period) }\end{array}$} & \multirow{2}{*}{$\begin{array}{l}\text { 기간 차이 } \\
\text { (post-pre) }\end{array}$} & \multicolumn{2}{|c|}{ 차이검정 } \\
\hline & & & & & $\mathrm{t}$-통계치 & $\begin{array}{c}\text { 비모수검정 } \\
\text { p-value }\end{array}$ \\
\hline \multirow{6}{*}{ 유가증권시장 } & 코스피증가율(\%) & 14.74 & 3.52 & -11.22 & - & - \\
\hline & 공매도비중(\%) & 6.36 & 5.30 & -1.06 & $-8.16^{* * *}$ & 0.000 \\
\hline & & $(1.22)$ & $(1.02)$ & & & \\
\hline & 공매도거래량 & 9,246 & 9,498 & 252 & 0.98 & 0.663 \\
\hline & (1,000주) & $(1,962)$ & $(2,459)$ & & & \\
\hline & $\begin{array}{l}\text { 공매도거래대금 } \\
\text { (배마워) }\end{array}$ & $\begin{array}{l}33,572 \\
(8211)\end{array}$ & $\begin{array}{r}35,994 \\
(11,105)\end{array}$ & 2,422 & $2.15^{* *}$ & 0.101 \\
\hline \multirow{7}{*}{ 코스닥시장 } & 코스닥증가율(\%) & 5.25 & 33.16 & 27.91 & - & - \\
\hline & 공매도비중(\%) & 1.71 & 2.41 & 0.70 & $9.19^{* * *}$ & 0.000 \\
\hline & & $(0.36)$ & (0.85) & & & \\
\hline & 공매도거래량 & 4,597 & 7,613 & 3,016 & $16.40^{* * *}$ & 0.000 \\
\hline & (1,000주) & (750) & $(2,125)$ & & & \\
\hline & 공매도거래대금 & 526 & 1,503 & 977 & $14.99^{* * *}$ & 0.000 \\
\hline & (백만원) & (130) & (788) & & & \\
\hline
\end{tabular}

\section{3. 공매도 과열종목 지정효과의 실증 분석}

\section{1 표본기간과 자료}

본 연구에서 설정한 표본기간은 공매도 과열종목 지정제도가 변경되어 시행된 2017년 9월 25일부터 2019년 10월 31일까지의 511거래일이다. 이 기간의 과열종목으로 지정되어 연구에 사용된 표본은 총 1,347 건으로, 표본은 거래일에서 지정된 개별 종목을 지칭한다. 본 연구에서 
한국증권학회지 제49권 5호 (2020)

활용한 표본자료는 표본기간동안 공매도 과열 상태로 지정되었던 종목들과 공매도를 포함한 거래 자료이다. 공매도 과열종목에 대한 정보는 한국거래소가 홈페이지에서 공개적으로 제공하는 『공매도종합포털(short.krx.co.kr)』에서 입수했다. 공매도종합포털에는 공매도 과열종목으로 지정된 표본의 종목명, 지정일자, 지정유형, 지정 기준별 수치 등의 정보가 등재되어 있다. 개별 종목 수준의 공매도 변수인 공매도 거래량, 거래대금, 잔고수량, 잔고금액과 시장 전체 수준의 공매도 변수를 비롯한 거래자료들은 Fn-guide가 제공하는 Dataguide5를 이용하여 추출했다.

\section{2 표본 분석}

$<$ 표 3>에는 실증 연구에 사용된 표본이 상장된 시장과 유형별 분포가 요약되어 있다. 유가 증권시장에서 과열종목으로 지정된 표본은 총 255건으로, 표본기간동안 평균적으로 2 거래일 마다 1건이 지정되는 것으로 나타났다. 이 중 유형 1로 지정된 표본은 95건(37.25\%)이며, 유형 2 로 지정된 표본은 160 건(62.75\%)으로 집계되어 주가하락률의 크기가 공매도 거래 비중의 기준보다 지정 종목을 적출하는 영향력이 높은 요인으로 나타났다. 코스닥시장에서 과열종목 으로 지정된 표본은 총 1,092 건으로 유가증권시장 표본의 4 배를 초과하여 1 건이 새로 지정 되기까지 평균적으로 0.46 일마이 소요되는 것으로 나타났다. 코스닥에서 지정빈도가 가장 높은 유형은 변경된 지정 제도에 새롭게 추가된 유형 3로 522건(47.80\%)이다. 다음으로 지정빈도가 높은 표본은 유형 2로 469건(42.95\%)이며, 유형 1로 지정된 표본은 101건(9.25\%)으로 다른 유형에 비해 지정빈도가 상대적으로 낮은 것으로 조사되었다. 따라서 각 기준에 모두 부합해야 지정되는 유형 1 의 지정빈도가 다른 유형보다 가장 낮은 것은 유가증권시장과 코스닥시장에서 공통적인 결과이다.

$<$ 그림 2>의 표본기간의 일별 과열종목 지정 빈도를 보면 패널 $\mathrm{A}$ 의 유가증권시장에서 1 건 이상 표본이 지정된 거래일은 174 일로 지정 거래일의 평균 과열종목 표본수는 1.47 건이었다. 패널 $\mathrm{B}$ 의 코스닥시장에서 1 건 이상 표본이 지정된 거래일은 418 일로 유가증권시장보다 지정 빈도가 높았으며, 지정 거래일의 평균 과열종목 지정 표본수는 2.61 건으로 계산되었다. 이는 제 2 장에서 설명했듯이 공매도 과열종목 지정 요건이 유가증권시장보다는 코스닥시장보다 완화되었고, 새로운 기준의 부과로 지정 대상이 증가했기 때문이다.9) 또한 <표 $2>$ 와 <그림 $1>$ 에서 과열종목 지정제도 개정 후 기간에 코스닥시장의 공매도가 활성화한 결과에 기인한다.

9) 2018 년 10 월 22 일부터 국민연금의 주식대여가 중단되었다. 이는 대주시장에서 국민연금이 참여하여 대여되는 주식들이 공매도 투기에 활용될 수 있다는 부정적 여론으로 인해 조치한 결과이다. 국민연금 주식대여 중단 후 기간의 유가증권시장의 일평균 과열종목지정 빈도는 0.433 건으로 중단 전 기간에 비해 0.189 건 감소한 반면, 코스닥시장의 중단 후 기간에서는 2.315 건으로 0.412 건이 증가했다. 이는 모두 $5 \%$ 수준에서 유의적이다. 또한 국민연금 주식대여 중단 후 기간의 유가증권시장의 일평균 공매도거래대금비율은 $6.77 \%$ 로 중단 전 기간에 비해 $1.1 \%$ 증가한 반면, 코스닥시장의 중단 후 기간에서는 $2.59 \%$ 로 $0.1 \%$ 이 증가했다. 비록 유가증권시장과 코스닥시장에서 차이는 있지만, 양 시장을 합산한 전체 과열종목지정빈도와 공매도거래대금비율로 보면 국민연금의 주식대여 중단으로 인해 공매도가 감소한 결과로는 볼 수 없다. 
The Effect of KRX Halts on Overheated Short-selling Stocks

〈표 3〉 표본의 분포

\begin{tabular}{|c|c|c|c|c|c|c|c|c|}
\hline \multirow{2}{*}{ 시장 } & \multicolumn{2}{|c|}{ 유형 1} & \multicolumn{2}{|c|}{ 유형 2} & \multicolumn{2}{|c|}{ 유형 3} & \multicolumn{2}{|c|}{ 전체 } \\
\hline & 건 & 비중(\%) & 건 & 비중(\%) & 건 & 비중(\%) & 건 & 비중(\%) \\
\hline 유가증권 & 95 & 37.25 & 160 & 62.75 & - & - & 255 & 100 \\
\hline 코스닥 & 101 & 9.25 & 469 & 42.95 & 522 & 47.80 & 1,092 & 100 \\
\hline 전체 & 196 & 14.25 & 629 & 46.70 & 522 & 38.75 & 1,347 & 100 \\
\hline
\end{tabular}

〈그림 2〉 표본기간의 일별 과열종목 지정 빈도

패널 $\mathrm{A}$ : 유가증권시장

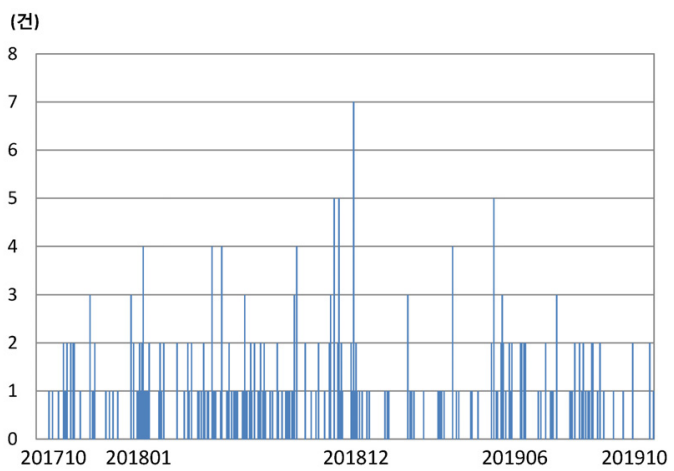

패널 $\mathrm{B}$ : 코스닥시장

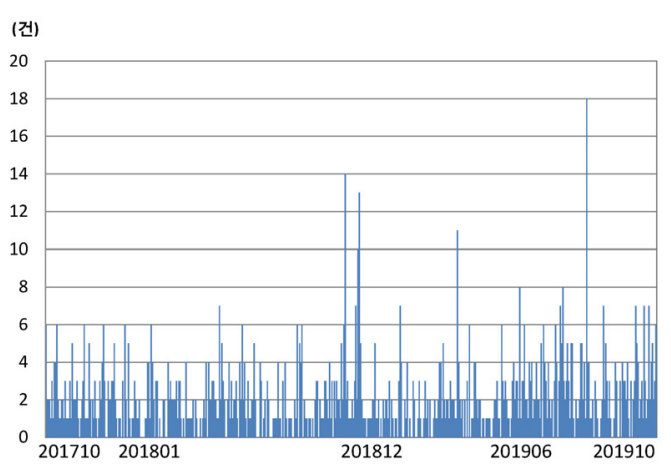

<표 4>에서 표본기간내에서 과열종목으로 지정된 빈도에 따른 종목수의 분포를 보면 유가증권시장에서 최소 1 건 이상 지정되었던 종목수는 총 200 종목이며, 코스닥시장에서 최소 1 건 이상 지정되었던 종목수는 총 518 종목으로 유가증권시장 종목의 2 배를 초과한다. 유가증권 시장에서 1건만 지정된 종목수는 163 종목(81.5\%)으로 집계되었다. 반면 코스닥시장에서 1 건만 지정된 종목수는 297건으로 57.3\%였으며, 2건 이상 고빈도 지정 종목수의 비중은 $42.7 \%$ 를 차지했다. 유형별로 지정빈도의 분포를 분석한 결과, 유형 1 로 지정된 유가증권시장 종목수는 총 78종목이며, 코스닥시장 상장 종목수는 83종목으로 집계되었다. 유형 1에서 1건만 지정되었던 유가증권시장 종목은 66개(84.6\%)이며 코스닥시장 종목도 69개(83.1\%)로 집계되어 유사한 분포를 보였다.10)

유형 2로 지정된 유가증권시장 종목수는 141 개이며, 코스닥시장 종목수는 374 개로 집계되었다. 코스닥시장에서 2 건 이상 지정된 종목은 $21.1 \%$ (79개)로 유형 1 에 비해 지정된 빈도가 높았다. 코스닥시장 종목만이 지정된 유형 3 에서는 2 건 이상 지정된 종목의 비율은 $64.2 \%$ 로 유형 1 과 유형 2에 비해 반복적으로 지정되는 종목들이 많았다.

10) 동일시장에서라도 1 개 종목은 표본기간동안 상이한 유형의 과열종목으로 지정될 수 있으므로 동일시장에서 유형별 지정빈도별 종목수의 합은 동일시장 전체 종목수의 합과 차이가 있다. 예를 들어, 어떤 종목이 유형 1 과 유형 2에 각각 1 회 지정되었다고 한다면 유형 1 과 유형 2 에서 각각 지정빈도 1 회로 집계되지만 전체 지정빈도는 2 회로 집계된다. 
한국증권학회지 제49권 5호 (2020)

〈표 4〉 지정 빈도건별 종목수

\begin{tabular}{|c|c|c|c|c|c|c|c|}
\hline \multirow{2}{*}{ 지정빈도 } & \multicolumn{2}{|c|}{ 유형 1} & \multicolumn{2}{|c|}{ 유형 2} & 유형 3 & \multicolumn{2}{|c|}{ 전체 } \\
\hline & 유가증권 & 코스닥 & 유가증권 & 코스닥 & 코스닥 & 유가증권 & 코스닥 \\
\hline 1 & 66 & 69 & 122 & 295 & 68 & 163 & 297 \\
\hline 2 & 8 & 11 & 19 & 64 & 49 & 26 & 99 \\
\hline 3 & 3 & 2 & 0 & 14 & 19 & 4 & 43 \\
\hline $4 \sim$ & 1 & 1 & 0 & 1 & 54 & 7 & 79 \\
\hline 전체 & 78 & 83 & 141 & 374 & 190 & 200 & 518 \\
\hline
\end{tabular}

<표 5>에는 과열종목으로 지정된 표본의 지정일의 각 기준의 평균치를 제시한다. 유가증권시장 에서 유형 1 로 지정된 표본의 지정일 평균 공매도비중은 $24.5 \%$ 였으며 주가수익률은 $-6.07 \%$ 였다. 직전 40거래일 평균 공매도대금 대비 지정일의 공매도대금인 공매도 거래대금 증가율은 9.09 배로 기준치를 크게 초과했다. 유형 2 의 지정일의 주가수익률은 $-13.64 \%$ 였으며, 직전 40 거래일 평균 공매도대금 대비 지정일의 공매도대금은 12.22 배로 유형 1 보다 높았다.

코스닥시장에서 유형 1 로 지정된 종목들의 공매도 비중은 $20.95 \%$ 였으며 주가수익률은 $-6.27 \%$ 였다. 직전 40거래일 평균 공매도대금 대비 지정일의 공매도대금은 8.89 배로 나타났다. 유형 2 의 지정일의 주가수익률은 $-12.95 \%$ 였으며, 직전 40 거래일 평균 공매도대금 대비 지정일의 공매도대금은 8.82 배로 유가증권시장의 유형 2 보다 낮았다. 유형 3 로 지정된 종목들의 평균 주가수익률은 $1.75 \%$ 로 유가증권시장과 코스닥시장의 유형 1 과 유형 2 와 달리 양의 값으로 $1 \%$ 수준에서 통계적으로 유의적이었다. 지정일 공매도 거래대금 증가율은 6.73 배이며, 과거 40 일 평균 공매도 비중은 $6.22 \%$ 였다.

〈표 5〉과열종목 지정 기준 변수의 지정일 평균

\begin{tabular}{|c|c|c|c|c|c|}
\hline 시장 & \multicolumn{2}{|c|}{ 유가증권 } & \multicolumn{3}{|c|}{ 코스닥시장 } \\
\hline 유형 & 유형 1 & 유형 2 & 유형 1 & 유형 2 & 유형 3 \\
\hline 당일공매도비중(\%) & 24.50 & & 20.95 & & \\
\hline 주가수익률(\%) & -6.07 & -13.64 & -6.27 & -12.95 & 1.75 \\
\hline 공매도 거래대금 증가율(배) & 9.09 & 12.22 & 8.89 & 8.82 & 6.73 \\
\hline 과거 40 일공매도 비중평균(\%) & & & & & 6.22 \\
\hline
\end{tabular}

\section{3 방법론}

본 연구에서 사용한 실증 분석의 방법론은 사건연구(event study)이다. 사건연구를 통해 검증하는 과열종목 지정제도의 성과 측정치는 과열종목 지정 요건에 해당하는 변수인 주식수익률과 공매도거래비율이며, 추가적으로 일중 변동성을 추가했다. 일중 변동성 지표는 한국거래소가 운영하고 있는 단기과열완화장치의 과열지표 기준 중 하나이며, 매매중단장치의 실효성을 검증한 선행연구들에서도 선정되어 성과를 측정할 때 용이한 지표이다. 즉, 본 연구는 박종원과 이우백 (2016)의 연구에서 단기과열완화장치의 실효성을 평가하기 위한 지표로 선정했던 수익률, 거래대금 회전율, 변동성에서 거래대금회전율을 공매도거래비율로 대체하여 분석한다. 
The Effect of KRX Halts on Overheated Short-selling Stocks

개별종목 $(i)$ 의 일별 $(t)$ 성과 측정치는 시장평균 수준을 고려하지 않은 원측정치와 해당 종목이 상장된 시장평균측정치를 차감한 초과측정치를 사용한다.11) 원측정치에서 시장평균측정치를 차감한 초과수익률(abnormal return: $A R$ ), 초과변동성(abnormal volatility; $A B V O L$ ), 초과 공매도거래비율(abnormal short trading ratio; $A S T R$ )은 다음 식 (1)과 같이 정의한다.

$$
\begin{aligned}
& A R_{i, t}=R_{i, t}-R_{M, t} \\
& A B V O L_{i, t}=V O L_{i, t}-V O L_{M, t} \\
& A S T R_{i, t}=S T R_{i, t}-S T R_{M, t}
\end{aligned}
$$

여기에서 $M \in\{K O S P I, K O S D A Q\}$

$A R_{i, t}$ 의 계산에서 $R_{i, t}$ 는 로그수익률로, 해당 종목이 유가증권시장 상장 종목이면 시장수익률로 코스피 로그수익률을 차감하며 코스닥시장 상장 종목이면 코스닥지수 로그수익률을 차감한다. 개별 종목의 변동성 지표 $\left(V O L_{i, t}\right)$ 는 일별로 (고가-저가)/\{(고가+저가)/2\}로 측정하며, 시장평균 변동성 $\left(V O L_{M, t}\right)$ 도 해당 종목이 상장된 시장의 주가지수의 고가와 저가에 대해 동일한 방법으로 측정하여 초과변동성을 계산한다.12) 공매도 행태의 대용변수인 공매도거래비율 $\left(S T R_{i, t}\right)$ 은 일별 전체 거래대금 대비 공매도금액의 비율로 측정하며, 과열종목 지정제도의 기준인 공매도비중과 동일하다. 초과공매도거래비율은 공매도거래비율에서 시장공매도거래비율 $\left(S T R_{M, t}\right)$ 을 차감하여 계산한다. $S T R_{M, t}$ 은 해당 종목이 소속된 시장의 전종목의 거래대금 대비 공매도 금액으로 측정한다.13)

사건연구에서 기본 사건기간은 과열 종목으로 지정된 거래일을 '지정일' $(t=0)$ 으로 정하고, 지정일을 포함한 과거 21 거래일 $(t=-20 \sim t=0)$ 을 '지정 전 기간(pre-event period)'으로 설정하며, 지정일 다음날부터 20거래일 $(t=1 \sim t=20)$ 을 '지정 후 기간(post-event period)'으로 설정한다. 물론, 사건기간을 지정일 전·후 20 일로 설정한 것은 달력일로는 평균 1 개월이지만, 과열종목 지정이라는 공시의 정보 효과의 지속성을 간과하며 실무 또는 학술적 근거가 부족하다. 따라서 공시의 정보 효과의 지속 기간을 지정 전·후 기간을 10 일부터 30 일까지 연장하여 분석한 결과로부터 사건일 설정 효과로부터 강건한지를 재검토하기로 한다.

과열종목 지정제도의 실효성은 식 (1)의 원측정치와 초과측정치에 대해 지정 전 기간과 지정 후 기간에 포함되는 $T_{1}$ 일부터 $T_{2}$ 일까지 식 (2)에서 제시되는 표본 평균치의 지정일 전· 후

11) 초과 측정치를 측정하는 대안적인 방법으로는 개별 종목에 대해 과거 일정 기간의 평균의 초과치로도 측정할 수 있지만, 공매도 과열종목 지정 요건에서 공매도의 과거 40 일간 평균치에 대비하여 유의 적으로 증가한 공매도 종목이 표본이 선정되므로 암묵적으로 일정 수준의 초과 측정치를 평가했다고 볼 수 있다.

12) 대안적인 변동성 지표로 사건기간동안 개별종목 수익률의 표준편차로 측정한 원측정치와, 이로부터 시장수익률의 표준편차를 차감한 초과측정치로도 실증분석을 수행한 결과도 고가와 저가 차이로 계산한 변동성의 분석결과와 통계적인 질적 해석과 일관성을 보였다. 이에 대해서는 제 3 장에서 설명한다.

13) 따라서 개별 종목의 공매도거래비율에 대해 해당 종목의 거래대금을 가중치로 평균한 공매도거래 비율이다. 
기간의 차이에 대한 통계적 유의성으로 판단한다. 또한 개별 표본에 대해 기간별 평균 차이를 비모수검정(non parametric test)으로 평가하여 전체 표본의 분석 결과와 개별 표본의 분석 결과의 일관성을 비교한다. 아울러, 시장 내에서 지정 유형에 따른 성과의 차이는 특정 유형에 속한 표본들의 측정치의 기간 차이와, 다른 유형에 속한 표본들의 기간 차이의 차이에 대한 검증(difference-in-difference test)으로 수행하여 지정 유형에 따라 선정된 표본에 대해 매매중단이 미치는 효과를 검증한다.

$$
\begin{aligned}
& \operatorname{CAR}_{\left[T_{1}, T_{2}\right]}=\frac{1}{N} \sum_{i=1 t}^{N} \sum_{t=T_{1}}^{T_{2}} A R_{i, t} \\
& \overline{A V O L}_{\left[T_{1}, T_{2}\right]}=\frac{1}{N} \sum_{i=1}^{N}\left(\frac{1}{T} \sum_{t=T_{1}}^{T_{2}} A V O L_{i, t}\right) \\
& \overline{A S T R}_{\left[T_{1}, T_{2}\right]}=\frac{1}{N} \sum_{i=1}^{N}\left(\frac{1}{T} \sum_{t=T_{1}}^{T_{2}} A S T R_{i, t}\right)
\end{aligned}
$$

여기에서 $N$ : 표본수

$T: T_{1}$ 일부터 $T_{2}$ 일까지 거래일

본 방법론을 적용하여 기존 이론 및 실증적 선행연구의 결과로부터 예상할 수 있는 가설은 다음과 같다. 만일 공매도 단기과열 종목 지정이 해당 종목 매매행태의 이상거래 또는 불공정 거래와 관련되었다는 신호를 순기능적으로 시장에 전달한다면 투자자간 정보비대칭이 해소되며 과열 상태가 냉각될 것이다. 따라서 과열종목 지정 후에 지표들은 지정 전 기간의 노이즈 거래(noise)가 내포된 수치보다 감소할 것이다. 그렇지만 이러한 순기능에 대립되는 역기능적 가능성도 두 가지로 생각해볼 수 있다. 첫째로 공매도 과열 종목으로 판단된 종목들의 매매행태가 노이즈 거래가 아닌 진정한 정보에 근거한 거래일 수도 있다. 이는 과열종목 지정이 실제로는 그릇된 신호를 시장에 전달하는 경우이며, 거래자들의 참여를 인위적으로 제한하여 새로운 정보가 반영되는 것을 방해할 것이다. 따라서 과열종목 지정 후의 가격은 비효율적으로 결정된다. 두 번째로는 과열종목으로 판단된 종목들의 공매도 행태가 노이즈 거래이라 하더라도 투자자들의 정보비대칭을 해소하려는 매매중단장치가 오히려 시장에 오인신호를 전달하여 투자자의 노이즈 거래를 증폭시키고, 역선택의 문제를 초래할 수 있다. 이러한 경우에도 과열종목 지정제도는 정보비대칭을 감소시키지 못하며 오히려 확대되어 지표들이 지정 전 기간에 비해 유의하게 감소하지는 않을 것이다.

\section{4 실증분석 결과}

제 3장에서는 과열종목 표본에 대해 과열종목 지정에 내포된 시장경보의 정보효과를 주가, 변동성, 공매도거래비율의 순서대로 분석한다.

\subsection{1 주가}

유가증권시장에서 공매도 과열종목으로 지정된 표본들은 <그림 3>의 패널 $\mathrm{A}$ (유형 1)와 
The Effect of KRX Halts on Overheated Short-selling Stocks

패널 $\mathrm{B}$ (유형 2)로 구분하여 제시된다. 유형 1 에서 $C A R$ 가 전체 사건기간 동안 누적수익률 (cumulative return: $C R$ )을 하회하는 패턴은 표본의 주가하락률이 시장지수의 하락률을 지속적으로 초과했음을 의미한다. 유형 1 의 지정일 20 일 전의 $0.318 \%$ 였던 $C A R$ 는 지정일 직전일까지 $-2.75 \%$ 까지 하락했으며, 지정일에는 초과수익률이 추가적으로 $6.47 \%$ 하락하여 $C A R_{[-20,0]}$ 는 $-9.22 \%$ 이다. 지정일 다음날인 공매도 중단일부터 20 일까지의 $C A R_{[1,20]}$ 는 $-1.77 \%$ 로 지정일 전까지 누적초과수익률인 $-2.75 \%$ 보다 높은 수준이다. 따라서 지정일 후의 단기적 $C A R$ 로 볼 때 시장과 대비한 과열종목 주가의 하락속도는 지정일 전 기간으로 회복된 것으로 해석된다. 패널 $\mathrm{B}$ 에 제시된 유형 2 의 $C A R$ 도 $C R$ 을 상회하지만 유형 1 과 달리 지정일까지 상승하다 지정일에 급락하여 과열 종목으로 지정되는 모습을 보인다. 지정일 하루 전까지의 $C A R_{[-20,-1]}$ 는 $14.26 \%$ 였으나, 지정일 하루의 초과수익률은 $-15.96 \%$ 로 지정일 전까지의 가격상승을 잠식했다. 지정일 다음날부터 20 일까지의 $C A R_{[1,20]}$ 는 $-1.35 \%$ 로 급격한 변동없이 수평적 패턴을 보이며, 이는 주가 변동이 완화되었음을 시사한다. 이같은 유형 2 의 결과는 과대평가 가능성이 높은 종목들에 대해 공매도가 본질 가격으로 회귀시키는 과정에서 추가적인 공매도의 집중을 제한하여 그 이후의 가격변동의 효과가 소멸한 것으로 해석할 수 있다.

〈그림 3〉 유가증권시장 공매도 과열종목 지정 전 · 후 유형별 누적수익률과 누적초과수익률 2017년 9월 25일부터 2019년 10월 31일까지 유가증권시장의 공매도 과열종목 지정일 기준으로 전 기간 $(-20,0)$ 과 지정 후 기간 $(1,20)$ 의 지정유형별 누적수익률 $(C R)$ 과 누적초과수익률 $(C A R)$ 이다.

패널 $\mathrm{A}:$ 유형 1

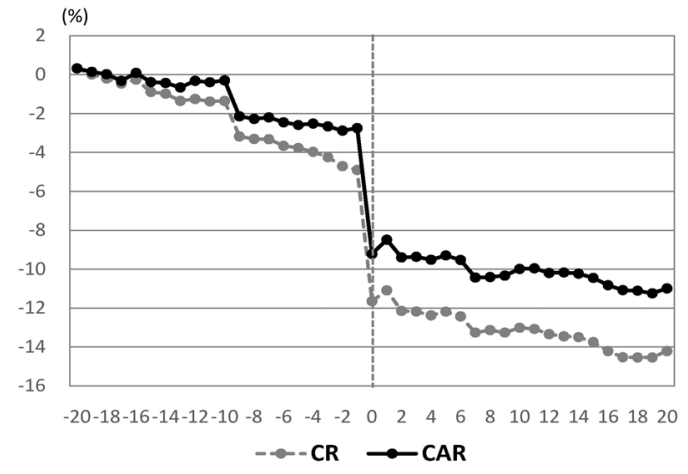

패널 $\mathrm{B}:$ 유형 2

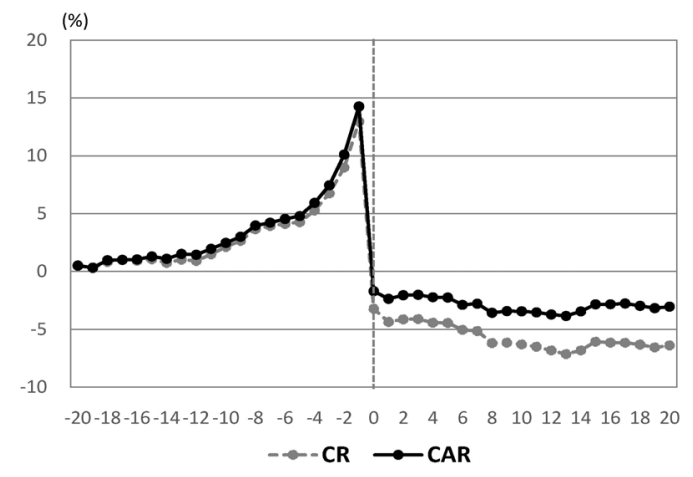

<그림 4>에 제시된 코스닥시장 유형 1 과 유형 2 의 과열종목으로 지정된 표본의 지정일 전·후 $C R$ 과 $C A R$ 도 유가증권시장의 패턴과 유사하다. 유형 1 과 달리, 유형 2 는 지정일 전까지 상승추세를 지속하다 지정일에 급락하여 과열 종목으로 지정되는 특성을 가진다. 그러나 코스닥시장의 유형 1 과 2에서도 지정 후 기간동안 일별 $C A R$ 에서 뚜렷한 방향성의 추세가 진정되는 패턴을 보인다. 패널 $\mathrm{C}$ 의 유형 3 은 유형 1 과 유형 2 와 상이한 주가행태를 보인다. $C A R$ 는 지정일에 $6.11 \%$ 까지 지속적으로 상승했지만, 지정일 다음날인 공매도 중단일부터 20 일 후까지 $C A R$ 는 $5.06 \%$ 까지 하락한다. 즉, 지정 후 20 일까지의 $C A R_{[1,20]}$ 는 $-1.05 \%$ 로 주가의 반전현상이 관찰된다. 만일 유형 3 의 표본의 지정 전까지의 주가행태가 노이즈 거래에 따른 
과민반응(overreaction)에 기인한 현상이라면, 공매도 중단이 없을 경우 주가의 반전현상이 강할 것이다. 유형 3 에서 관측된 반전현상의 통계적 유의성과 경제적 유의성이 낮다면, 과열종목 지정의 정보효과와 공매도 중단의 냉각 기간은 과민반응에 후속할 반전을 제어하는 효과를 가진 것으로 평가할 수 있다. 유형 1 과 2 와 달리, 유형 3 로 지정되는 종목에는 공매도 증가와 비중의 요인만이 영향을 미친다. 유형 3의 표본들의 주가상승이 본질가치에 수렴하는 과정이라면 공매도 지정은 가격발견을 저해하는 역기능을 가질 것이다. 이를 검정하기 위해 유형 3 의 표본을 지정 전 기간의 누적수익률을 기준으로 0보다 크면 '상승 표본', 그렇지 않으면 '하락 표본'으로 분류하여 양 표본 집단의 지정 후 기간의 $C A R$ 을 비교했으며, 지정 당일의 수익률에 대해서도 역시 부호에 따라 상승(+)과 하락(-) 표본으로 구분하여 동일한 분석을 적용했다.

〈그림 4〉 코스닥시장 공매도 과열종목 지정 전 · 후 유형별 누적수익률과 누적초과수익률 2017년 9월 25일부터 2019년 10월 31일까지 코스닥시장의 공매도 과열종목 지정일 기준으로 전 기간 $(-20,0)$ 과 지정 후 기간 $(1,20)$ 의 지정유형별 누적수익률 $(C R)$ 과 누적초과수익률 $(C A R)$ 이다.

패널 $\mathrm{A}:$ 유형 1

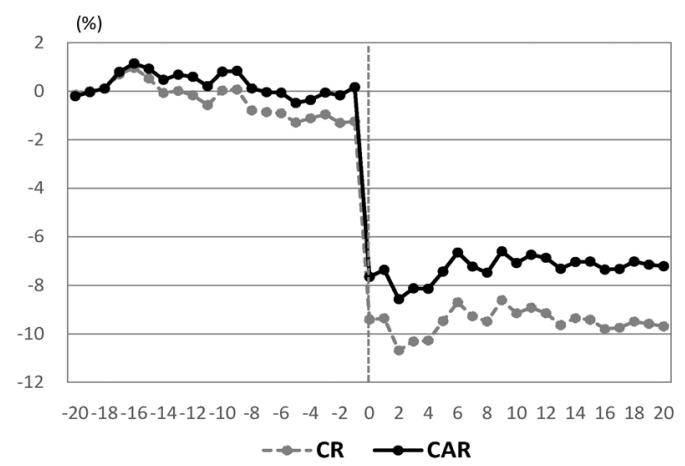

패널 C: 유형 3

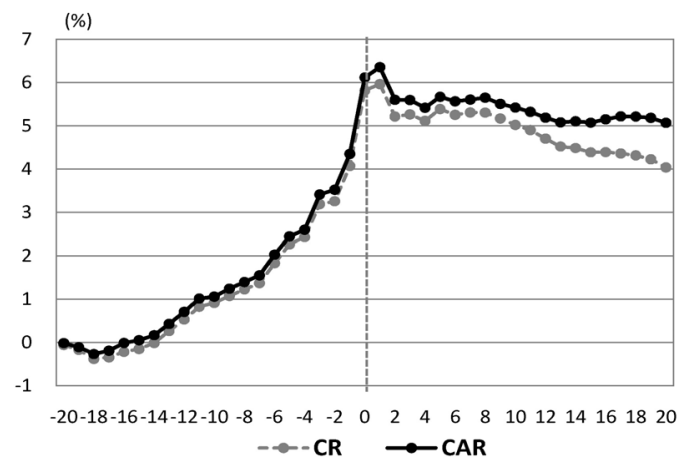

패널 $\mathrm{B}:$ 유형 2

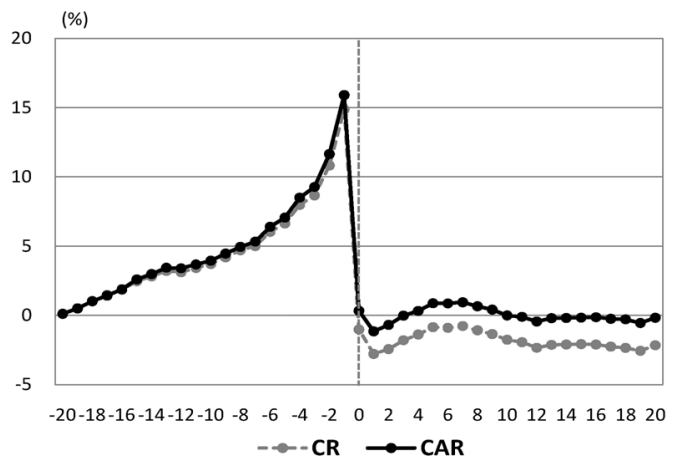

지정 전 기간의 수익률을 기준으로 상승 표본의 지정 후 기간의 $C A R$ 은 $-0.23 \%$ 였으며, 하락 표본의 지정 후 기간의 $C A R$ 은 $-2.28 \%$ 로 나타나 공매도 과열 지정은 각 표본의 방향 추세를 완화하는 효과를 보였다. 또한 지정 후 기간의 상승 표본과 하락 표본간 수익률간 차이에서도 
The Effect of KRX Halts on Overheated Short-selling Stocks

통계적 유의성은 발견되지 않았다.14) 즉, 상승 표본은 유형 2 와 유사하게 과대평가 가능성이 높은 종목들에 대해 공매도가 본질 가격으로 회귀시키는 과정에서 추가적인 공매도의 집중을 제한하여 그 이후의 가격변동의 효과가 소멸한 것으로 해석할 수 있다. 반면, 공매도의 증가로 인한 하락 과정에 있는 표본에 대해서도 공매도를 차단하여 추가적인 하락 속도를 제어하는 효과를 가진다. 또한 지정 당일의 수익률을 기준으로 동일한 방법을 적용해도 지정 후 기간의 상승 표본과 하락 표본의 초과수익률은 각각 $-1.60 \%$ 와 $-0.33 \%$ 로 $10 \%$ 수준에서 통계적으로 비유의적이며, 표본간의 차이에서도 역시 유의성은 발견할 수 없었다.15)

<표 6>에는 <그림 3>과 <그림 4>에서 관찰한 유가증권시장과 코스닥시장의 과열종목 지정 유형에 따른 지정일 전 20 일과 지정일, 그리고 지정 후 20 일간 기간별 $C R$ 과 $C A R$ 에 대한 통계적 유의성을 검증한 결과이다. $C R$ 은 $C A R$ 과 수치에서 차이가 있으나 분석결과의 실증적 해석은 질적으로 동일하므로 $C A R$ 를 중심으로 설명한다. 먼저. $C A R_{[-20,0]}$ 유가증권시장의 유형 1 표본의 결과에서 지정 전 기간의 $C A R_{[-20,0]}$ 은 $-9.22 \%$ 이며 $\mathrm{t}$-검정과 비모수검정에서 모두 $1 \%$ 수준에서 유의하다. 지정 후 기간의 $C A R_{[1,20]}$ 은 $-1.77 \%$ 로 t검정에서 유의성을 발견하지 못했지만, 비모수검정에서는 $5 \%$ 수준에서 유의적인 것으로 나타났다. 양 기간의 $C A R$ 의 차이는 $7.46 \%$ 포인트로, $1 \%$ 수준에서 이 차이는 유의적이다. 따라서 이러한 실증 결과는 과열종목 지정이 지정 전 기간에 비해 지정 후 기간의 주가하락 속도를 유의적으로 제어했다는 실질적 효과로 평가할 수 있다. 지정유형 2 의 지정 전 기간의 $C A R$ 는 $-1.70 \%$ 로 $\mathrm{t}$ 검정에서는 유의성을 발견할 수 없었던 반면, 비모수검정에서는 $5 \%$ 수준에서 유의적이다. 지정 후 기간의 $C A R_{[0,20]}$ 는 $-1.35 \%$ 로 지정 전 기간과 같이 t검정에서는 비유의적이며, 비모수검정에서는 $5 \%$ 수준에서 비유의적으로 분석되었다. 즉, $\mathrm{t}$ 검정과 비모수검정을 종합할 경우 지정 후 기간의 초과수익률은 0 과 다르지 않다고 할 수 있다. 또한 양 기간 $C A R$ 의 차이는 $0.35 \%$ 포인트이며, 비모수검정의 유의확률도 0.098 에 불과하므로 기간간 $C A R$ 차이는 비유의적이라고 판단할 수 있다. 이렇게 지정 후 기간에 추가적 주가하락을 제어하여 지정 전 기간의 수준으로 유지시키는 결과를 볼 때, 과열종목 지정제도의 취지에 부합하는 효과로 평가된다. 또한 지정 전 기간의 유형 1 의 유형 2 의 표본간 $C A R$ 차이는 $7.52 \%$ 포인트에서 지정 후 기간의 유형간 차이는 $-0.42 \%$ 포인트로 대폭적으로 감소하였다. 이같은 결과는 과열종목 지정 전 유형별로 상이한 주가행태가 지정 후에는 공통적으로 과열상태를 억제하는 방향으로 수렴되었음을 설명한다.

하단의 코스닥시장을 보면 유형 1 표본의 결과에서 $-7.64 \%$ 로 t-검정과 비모수검정에서 모두 $1 \%$ 수준에서 유의적이었던 지정 전 기간의 $C A R_{[-20,0]}$ 는 지정 후 기간에 $0.43 \%$ 로 반전되어 통계적 유의성이 소멸되었다. 유형 2 에서는 지정 전 기간과 지정 후 기간의 $C A R$ 는 $\mathrm{t}$ 검정과

14) 유형 3 에서 지정 전 기간의 상승 표본은 312 건(59.77\%)이며 평균누적수익률은 $16.12 \%$ 이며, 하릭 표본의 지정 전 기간의 평균누적수익률은 $-9.04 \%$ 였다. 상승 표본과 하락 표본의 지정 후 기간의 초과수익률의 평균 차이에 대한 t-검정 결과는 $5 \%$ 수준에서 비유의적이었다.

15) 지정일의 주가 상승 표본은 293 건으로 주가 하락 표본보다 많았으며, 지정일 주가 상승 표본과 지정일 주가 하락 표본의 지정 후 기간의 $C A R$ 의 차이 결과에서 $\mathrm{t}$-통계치는 -0.88 이며 비모수 Wilcoxon 검정의 $\mathrm{p}^{-}$value도 0.238 였다. 
비모수검정에서 유의성을 모두 발견할 수 없었으며, 기간 차이도 비유의적이다. 이같은 결과는 유가증권시장과 유사하다. 유형 3 의 지정 전 기간의 $C A R$ 는 $6.11 \%$ 로 $1 \%$ 수준에서 유의적이며, 지정일의 초과수익률이 $1.77 \%$ 로 지정 전 $C A R$ 의 $6.11 \%$ 의 $28.87 \%$ 를 기여한다. 지정 후 기간의 $C A R_{[1,20]}$ 는 $-1.05 \%$ 로 $5 \%$ 수준에서 비모수검정 결과 지정 전 기간의 주가의 상승추세가 제한된 효과가 나타난다. 지정일의 초과수익률의 상승에 따라 공매도가 급증했다면, $C A R_{[1,20]}$ 의 크기로 볼 때 과민반응으로 인한 주가하락을 제어한다는 점에서 제도의 실효성이 있다고 평가된다. 지정 전 기간의 코스닥시장의 유형의 표본간 $C A R$ 차이는 모두 통계적으로 유의적이었지만

〈표 6〉 공매도 과열종목 지정 전 - 후 누적수익률과 누적초과수익률

2017년 9월 25일부터 2019년 10월 31일까지 공매도 과열종목 지정 전 기간 $(-20,0)$ 과 지정 후 기간 $(1,20)$ 의 누적수익률 $(C R)$ 과 누적초과수익률 $(C A R)$ 의 표본 평균 차이에 대한 검정결과이다. 첫 번째 값은 평균, 두 번째 괄호안의 값은 $\mathrm{t}$ 통계치, 세 번째 각괄호안의 값은 비모수검정의 유의확률(p-value)이다. * , ${ }^{*}$, ***는 각각 $10 \%, 5 \%, 1 \%$ 수준에서 유의적이다.

\begin{tabular}{|c|c|c|c|c|c|c|c|}
\hline \multirow[t]{2}{*}{ 시장구분 } & \multirow[t]{2}{*}{ 지정유형 } & \multicolumn{2}{|c|}{$\begin{array}{l}\text { 지정 전 기간 } \\
\text { (pre period) }\end{array}$} & \multicolumn{2}{|c|}{$\begin{array}{l}\text { 지정 후 기간 } \\
\text { (post period) }\end{array}$} & \multicolumn{2}{|c|}{$\begin{array}{l}\text { 차이 검정 } \\
\text { (post-pre) }\end{array}$} \\
\hline & & 수익률 & 초과수익률 & 수익률 & 초과수익률 & 수익률 & 초과수익률 \\
\hline \multirow{9}{*}{$\begin{array}{c}\text { 유가증권 } \\
(\%)\end{array}$} & \multirow[t]{3}{*}{1} & -11.65 & -9.22 & -2.56 & -1.77 & 9.09 & 7.46 \\
\hline & & $(-5.52)^{* * *}$ & $(-4.73)^{* * *}$ & $(-2.12)^{* *}$ & $(-1.59)$ & $(3.74)^{* * *}$ & $(3.32)^{* * *}$ \\
\hline & & {$[0.000]$} & {$[0.000]$} & [0.024] & [0.046] & {$[0.000]$} & {$[0.000]$} \\
\hline & \multirow[t]{3}{*}{2} & -3.22 & -1.70 & -3.18 & -1.35 & 0.05 & 0.35 \\
\hline & & $(-1.39)$ & $(-0.78)$ & $(-2.08)^{* *}$ & $(-0.91)$ & $(-0.02)$ & $(0.13)$ \\
\hline & & {$[0.006]$} & [0.020] & [0.002] & [0.060] & [0.169] & [0.098] \\
\hline & \multirow{3}{*}{$\begin{array}{l}\text { 차이 검정 } \\
(1-2)\end{array}$} & -8.43 & -7.52 & 0.62 & -0.42 & 9.04 & 7.10 \\
\hline & & $(-2.69)^{* * *}$ & $(-2.57)^{* *}$ & (0.32) & $(0.82)$ & $(2.37)^{* *}$ & $(2.03)^{* *}$ \\
\hline & & [0.192] & [0.359] & [0.498] & [0.935] & [0.184] & [0.578] \\
\hline & \multirow[t]{3}{*}{1} & -9.41 & -7.64 & -0.28 & 0.43 & 9.13 & 8.08 \\
\hline & & $(-5.93)^{* * *}$ & $(-4.78)^{* * *}$ & $(-0.15)$ & $(0.24)$ & $(-3.75)^{* * *}$ & $(3.37)^{* * *}$ \\
\hline & & {$[0.000]$} & {$[0.000]$} & [0.544] & [0.959] & {$[0.000]$} & {$[0.000]$} \\
\hline & \multirow[t]{3}{*}{2} & -1.01 & 0.34 & -1.14 & -0.51 & -0.13 & -0.84 \\
\hline & & $(-0.63)$ & $(0.21)$ & $(-0.99)$ & $(-0.45)$ & $(0.07)$ & $(-0.44)$ \\
\hline & & [0.140] & [0.611] & [0.082] & [0.192] & [0.572] & [0.928] \\
\hline & \multirow[t]{2}{*}{3} & 5.82 & 6.11 & -1.78 & -1.05 & -7.60 & -7.16 \\
\hline & & $(6.42)^{* * *}$ & $(7.08)^{* * *}$ & $(-2.28)^{* *}$ & $(-1.43)$ & $(6.35)^{* * *}$ & $(-6.32)^{* * *}$ \\
\hline \multirow{10}{*}{$\begin{array}{c}\text { 코스닥 } \\
(\%)\end{array}$} & & {$[0.000]$} & {$[0.000]$} & {$[0.001]$} & [0.011] & {$[0.000]$} & {$[0.000]$} \\
\hline & \multirow{3}{*}{$\begin{array}{c}\text { 차이 검정 } \\
(1-2)\end{array}$} & -8.40 & -7.98 & 0.86 & 0.94 & 9.26 & 8.92 \\
\hline & & $(-3.72)^{* * *}$ & $(-3.56)^{* *}$ & $(0.40)$ & $(0.45)$ & $(2.96)^{* * *}$ & $(2.90)^{* * *}$ \\
\hline & & [0.011] & [0.014] & [0.535] & [0.350] & [0.029] & [0.027] \\
\hline & \multirow{3}{*}{$\begin{array}{c}\text { 차이 검정 } \\
(1-3)\end{array}$} & -15.23 & -13.76 & 1.50 & 1.48 & 16.73 & 15.24 \\
\hline & & $(-8.33)^{* * *}$ & $(-7.57)^{* * *}$ & $(0.75)$ & $(0.77)$ & $(6.34)^{* * *}$ & $(5.85)^{* * *}$ \\
\hline & & {$[0.000]$} & {$[0.000]$} & [0.439] & [0.320] & {$[0.000]$} & {$[0.000]$} \\
\hline & \multirow{3}{*}{$\begin{array}{c}\text { 차이 검정 } \\
(2-3)\end{array}$} & -6.83 & -5.78 & 0.64 & 0.54 & 7.47 & 6.32 \\
\hline & & $(-3.70)^{* * *}$ & $(-3.22)^{* * * *}$ & $(0.46)$ & $(0.40)$ & $(3.18)^{* * *}$ & $(2.80)^{* * *}$ \\
\hline & & {$[0.000]$} & {$[0.000]$} & [0.942] & [0.833] & {$[0.000]$} & {$[0.000]$} \\
\hline
\end{tabular}


The Effect of KRX Halts on Overheated Short-selling Stocks

지정 후 기간의 유형간 $C A R$ 차이에서는 이와 대조적으로 그 유의성을 발견할 수 없었다. 이같은 결과는 과열종목 지정 전 유형별로 상이한 주가행태가 지정 후에는 공통적으로 과열상태를 억제하는 방향으로 수렴되었음이 확인된다.

$<$ 표 7>은 사건기간 설정의 강건성 검정(robustness check) 목적으로, 기본 분석의 지정 전 기간과 지정 후 기간일인 20 일 대신 10 일부터 30 일까지의 사건일을 적용하여 사건기간 설정이 분석 결과에 미치는 효과를 검토했다. 표에 제시된 $C A R$ 에 대한 결과를 보면, 유가증권 시장에서 유형 1 은 21 개의 모든 사건기간 분석에서 지정 전 기간보다 지정 후 기간의 음(-)의 $C A R$ 가 유의적으로 감소했으며, $\mathrm{t}$-검정과 비모수검정에서 $5 \%$ 수준에서 유의적인 것으로 확인되었다. 유가증권시장 유형 2 는 사건기간이 길어질수록, 지정 전 기간에 음의 누적초과 수익률의 크기가 감소하는 경향을 관찰할 수 있지만 어떠한 사건기간에서도 지정 후 기간의 $C A R$ 와 유의적인 차이를 발견할 수 없었다. 이는 <표 $6>$ 에서 사건기간을 20 일로 설정하여 분석한 결과와 일관성을 유지한다. 코스닥의 유형 1 표본의 21 개 지정 전 기간의 $C A R$ 는 모두

〈표 7〉 사건기간 설정에 따른 공매도 과열 종목 지정 전·후 초과수익률

2017년 9월 25일부터 2019년 10월 31일까지 공매도 과열종목 지정 전 기간 $(-t, 0)$ 과 지정 후 기간 $(1, t)$ 의 누적초과수익률 $(C A R)$ 의 표본 평균 차이에 대한 검정결과이다. 표에 제시된 값은 표본 평균으로, 차이 유의성에서 '*'는 $\mathrm{t}$-검정결과 $5 \%$ 수준에서 통계적으로 유의적이며, ' $\sqrt{ }$ '는 비모수검정결과 $5 \%$ 수준에서 유의적임을 의미한다.

\begin{tabular}{|c|c|c|c|c|c|c|c|c|c|c|c|c|c|}
\hline 시장 & \multicolumn{5}{|c|}{ 유가증권 } & \multicolumn{8}{|c|}{ 코스닥 } \\
\hline 유형 & \multicolumn{3}{|c|}{1} & \multicolumn{2}{|r|}{2} & \multicolumn{3}{|c|}{1} & \multicolumn{2}{|r|}{2} & \multicolumn{3}{|c|}{3} \\
\hline $\begin{array}{c}\text { 기간 } \\
(t)\end{array}$ & 전 & 후 & $\begin{array}{l}\text { 차이 } \\
\text { 유의성 }\end{array}$ & 전 & $\begin{array}{c}\text { 차이 } \\
\text { 유의성 }\end{array}$ & 전 & 후 & $\begin{array}{l}\text { 차이 } \\
\text { 유의성 }\end{array}$ & 전 & $\begin{array}{l}\text { 차이 } \\
\text { 유의성 }\end{array}$ & 전 & 후 & $\begin{array}{l}\text { 차이 } \\
\text { 유의성 }\end{array}$ \\
\hline 10 & -8.83 & -0.77 & $* \sqrt{ }$ & -3.65 & -1.75 & -7.85 & 0.57 & $* \sqrt{ }$ & -3.34 & -0.34 & 5.10 & -0.69 & $* \sqrt{ }$ \\
\hline 11 & -8.91 & -0.74 & $* \sqrt{ }$ & -3.14 & -1.84 & -8.24 & 0.91 & $* \sqrt{ }$ & -3.07 & -0.44 & 5.41 & -0.79 & $* \sqrt{ }$ \\
\hline 12 & -8.56 & -0.98 & $* \sqrt{ }$ & -3.21 & -2.02 & -8.33 & 0.78 & $* \sqrt{ }$ & -3.11 & -0.78 & 5.68 & -0.93 & $* \sqrt{ }$ \\
\hline 13 & -8.79 & -0.95 & $* \sqrt{ }$ & -2.79 & -2.15 & -8.12 & 0.33 & $* \sqrt{ }$ & -2.65 & -0.54 & 5.95 & -1.04 & $* \sqrt{ }$ \\
\hline 14 & -8.84 & -1.01 & $* \sqrt{ }$ & -2.99 & -1.75 & -8.58 & 0.61 & $* \sqrt{ }$ & -2.26 & -0.52 & 6.06 & -1.01 & $* \sqrt{ }$ \\
\hline 15 & -9.31 & -1.23 & $* \sqrt{ }$ & -2.73 & -1.14 & -8.79 & 0.63 & $* \sqrt{ }$ & -1.55 & -0.50 & 6.13 & -1.04 & $* \sqrt{ }$ \\
\hline 16 & -8.91 & -1.60 & $* \sqrt{ }$ & -2.71 & -1.13 & -8.44 & 0.29 & $* \sqrt{ }$ & -1.09 & -0.47 & 6.30 & -0.97 & $* \sqrt{ }$ \\
\hline 17 & -9.25 & -1.85 & $* \sqrt{ }$ & -2.66 & -1.07 & -7.75 & 0.32 & $* \sqrt{ }$ & -0.69 & -0.58 & 6.38 & -0.90 & $* \sqrt{ }$ \\
\hline 18 & -9.37 & -1.89 & $* \sqrt{ }$ & -2.03 & -1.27 & -7.61 & 0.63 & $* \sqrt{ }$ & -0.17 & -0.62 & 6.22 & -0.90 & $* \sqrt{ }$ \\
\hline 19 & -9.54 & -2.02 & $* \sqrt{ }$ & -2.21 & -1.47 & -7.44 & 0.50 & $* \sqrt{ }$ & 0.22 & -0.89 & 6.13 & -0.93 & $* \sqrt{ }$ \\
\hline 20 & -9.22 & -1.77 & $* \sqrt{ }$ & -1.70 & -1.35 & -7.64 & 0.43 & $* \sqrt{ }$ & 0.34 & -0.51 & 6.11 & -1.05 & $* \sqrt{ }$ \\
\hline 21 & -8.76 & -1.86 & $* \sqrt{ }$ & -1.56 & -1.44 & -7.57 & 0.32 & $* \sqrt{ }$ & 0.73 & -0.73 & 6.20 & -1.12 & $* \sqrt{ }$ \\
\hline 22 & -9.40 & -1.23 & $* \sqrt{ }$ & -1.37 & -1.60 & -7.69 & 0.44 & $* \sqrt{ }$ & 1.19 & -0.38 & 6.13 & -0.83 & $* \sqrt{ }$ \\
\hline 23 & -9.90 & -1.37 & $* \sqrt{ }$ & -1.59 & -1.42 & -7.95 & 0.95 & $* \sqrt{ }$ & 1.45 & -0.61 & 6.05 & -0.68 & $* \sqrt{ }$ \\
\hline 24 & -10.20 & -1.04 & $* \sqrt{ }$ & -1.46 & -1.36 & -8.41 & 1.11 & $* \sqrt{ }$ & 1.97 & -0.72 & 5.89 & -0.49 & $* \sqrt{ }$ \\
\hline 25 & -10.27 & -1.18 & $* \sqrt{ }$ & -1.14 & -1.58 & -8.12 & 0.97 & $* \sqrt{ }$ & 2.28 & -0.70 & 5.80 & -0.53 & \\
\hline 26 & -10.22 & -1.19 & $* \sqrt{ }$ & -0.74 & -2.18 & -7.77 & 0.93 & $* \sqrt{ }$ & 2.21 & -0.69 & 5.65 & -0.78 & $* \sqrt{ }$ \\
\hline 27 & -10.44 & -1.24 & $* \sqrt{ }$ & -0.66 & -2.08 & -8.03 & 0.96 & $* \sqrt{ }$ & 2.26 & -0.55 & 5.42 & -1.10 & $* \sqrt{ }$ \\
\hline 28 & -10.18 & -1.69 & $* \sqrt{ }$ & -0.43 & -2.20 & -8.10 & 0.48 & $* \sqrt{ }$ & 3.03 & -0.51 & 5.20 & -1.26 & \\
\hline 29 & -10.27 & -1.48 & $* \sqrt{ }$ & -0.30 & -1.89 & -8.08 & 0.70 & $* \sqrt{ }$ & 3.05 & -0.79 & 5.01 & -1.42 & $* \sqrt{ }$ \\
\hline 30 & -10.31 & -1.41 & $* \sqrt{ }$ & -0.07 & -1.49 & -7.80 & 0.34 & $* \sqrt{ }$ & 3.06 & -0.93 & 5.07 & -1.58 & $* \sqrt{ }$ \\
\hline
\end{tabular}


한국증권학회지 제49권 5호 (2020)

음의 값으로 측정된 반면, 지정 후 기간에는 양으로 반전되어 <표 6>의 결과와 유사하다. 또한 유가증권시장의 유형 1 표본의 검정결과와 같이, $\mathrm{t}$-검정과 비모수검정에서 21 개 사건기간별 분석에서 모두 5\% 수준에서 유의적인 차이가 발견되었다. 코스닥의 유형 2에서는 지정 전 사건기간일이 18 일까지 음의 $C A R$ 의 행태를 보였지만, 19 일부터는 양의 수치로 전환하여 증가하는 패턴을 보였다. 지정 후 사건기간일의 $C A R$ 는 음의 부호로 추정되었지만 0과 유의적인 차이가 없었다. 양 기간의 유의적인 차이가 확인된 사건기간은 12 일이내였으며, 그 후 기간에서는 유의성이 소멸되었다. 코스닥의 유형 3 은 유형 1 이나 유형 2 와 달리 전체 사건기간에서 지정 전 기간의 양의 $C A R$ 는 지정 후 기간에는 음의 $C A R$ 로 반전되었으며, 양 기간의 차이에 대해서도 $5 \%$ 수준에서 모두 유의적이었다. 이상의 내용은 <표 6>, <그림 3>, <그림 4>의 결과가 특정 사건기간 설정에만 국한된 개연성을 배제하며, 사건기간과 무관하게 일관성있는 효과임을 지지한다.

\subsection{2 변동성}

<그림 $5>$ 와 <그림 $6>$ 은 유가증권시장과 코스닥시장의 지정일 전·후 20 일간의 일별 변동성 행태를 제시한다. <그림 $5>$ 의 패널 $\mathrm{A}$ 의 유가증권시장의 유형 1 표본의 변동성 $(V O L)$ 과 초과변동성 $(A V O L)$ 을 보면 $A V O L$ 은 지정 전 기간에 $3 \%$ 미만에서 변동하다 지정일에 $6 \%$ 를 초과하는 수준으로 급등했지만, 지정 후 기간에는 지정 전 기간인 $3 \%$ 미만으로 회복되는 행태를 보인다. 패널 $\mathrm{B}$ 의 유형 2 에서도 지정일을 기준으로 지정 전·후 기간의 일별 변동성의 대칭적 패턴을 관찰할 수 있다. 유형 2 의 지정일의 $A V O L$ 는 $14.85 \%$ 로 유형 1 지정일의 2 배를 초과한다. 지정 전 기간에는 $V O L$ 과 $A V O L$ 은 지정 전 4거래일부터 지정일까지 변동성이 급속히 증가하는 추세를 보였지만, 지정일 다음날에 변동성 지표는 하락하여 지정 전 기간의 변동성 수준으로 복귀하는 패턴을 보인다. <그림 6>의 패널 $\mathrm{A}$ 부터 패널 $\mathrm{C}$ 까지 제시된 코스닥시장 과열 종목의 일별 변동성 패턴도 유가증권시장의 변동성 행태와 큰 차이가 없다. 각 지정 유형에서 지정일에 급등한 변동성을 중심으로 양 기간의 변동성은 대칭적인 행태를 보였다.

$<$ 그림 5>와 <그림 6>의 공매도 중단으로 인한 지정 전 기간과 지정 후 기간의 $V O L$ 과 $A V O L$ 행태의 차이의 유의성 여부를 통계적으로 검증한 결과는 <표 8>에서 점검한다. 표에서는 유형별로 기간 차이에 대한 $\mathrm{t}$-검정과 비모수검정, 그리고 각 유형별 개별 표본의 평균 차이에 대한 비모수검정에서 $5 \%$ 수준에서 유의적인 표본의 비율과 개별 표본의 지정 후 기간의 평균이 지정 전 기간의 평균보다 큰 표본의 비율을 제시한다. $V O L$ 은 $A V O L$ 과 수치에서 차이가 있지만 분석결과의 경제학적 해석은 질적으로 동일하므로, 초과측정치인 $A V O L$ 을 중심으로 설명한다. 유가증권시장의 유형 1 과 유형 2 의 지정 전·후 기간의 일평균 $A V O L$ 의 차이는 각각 $0.01 \%$ 와 $0.00 \%$ 이며, 이에 대한 t검정과 비모수검정의 결과도 양 기간의 평균치는 동일하다는 결과를 확증한다. 유형 2 의 지정 전·후 기간의 일별 $A V O L$ 은 $4.55 \%$ 로 유형 1 보다 크지만, 기간 간 차이에 대한 유형별 차이도 역시 비유의적이다. 코스닥시장에서 유형 1 도 지정 전·후 기간 $A V O L$ 의 유의적 차이는 없는 것으로 검증되었다. 유형 2 의 지정 전 $A V O L$ 은 $5.44 \%$ 로 유형 1 보다 높았지만, 지정 후 기간에 감소하여 비모수검정 결과에서 $5 \%$ 수준에서 유의적인 것으로 
The Effect of KRX Halts on Overheated Short-selling Stocks

〈그림 5> 유가증권시장 공매도 과열종목 지정 전 · 후 유형별 변동성과 초과변동성 2017년 9월 25일부터 2019년 10월 31일까지 유가증권시장의 공매도 과열종목 지정일 기준으로 전 기간 $(-20,0)$ 과 지정 후 기간 $(1,20)$ 의 지정유형별 변동성( $V O L)$ 과 초과변동성 $(A V O L)$ 이다.

패널 $\mathrm{A}$ : 유형 1

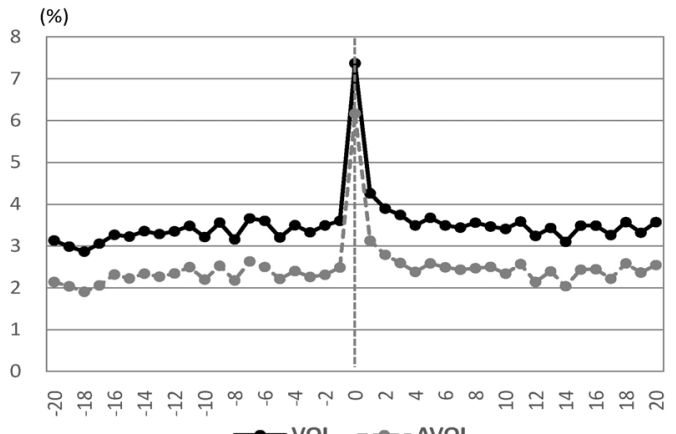

$\rightarrow$ VOL ---AVOL

\section{패널 B: 유형 2}

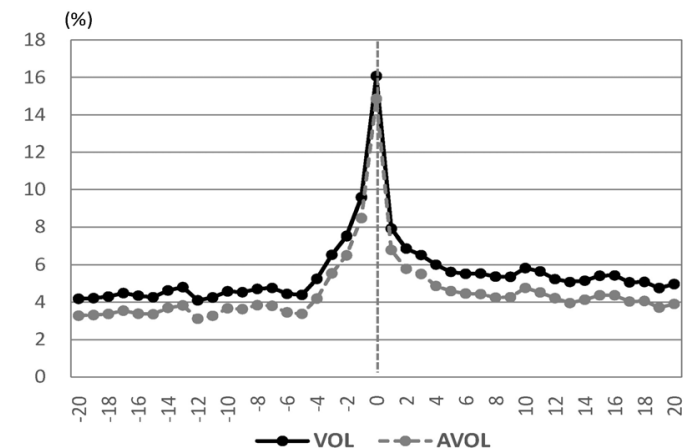

〈그림 6> 코스닥 공매도 과열종목 지정 전 · 후 유형별 변동성과 초과변동성

2017년 9월 25일부터 2019년 10월 31일까지 코스닥시장의 공매도 과열종목 지정일 기준으로 전 기간 $(-20,0)$ 과 지정 후 기간 $(1,20)$ 의 지정유형별 변동성 $(V O L)$ 과 초과변동성 $(A V O L)$ 이다.

패널 $\mathrm{A}$ : 유형 1

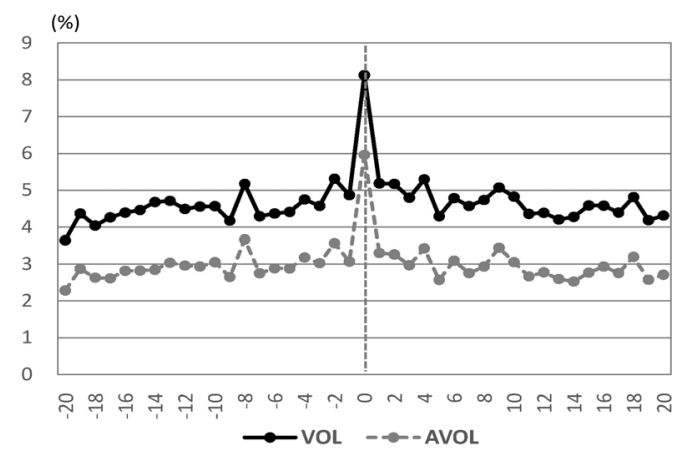

패널 $\mathrm{C}:$ 유형 3

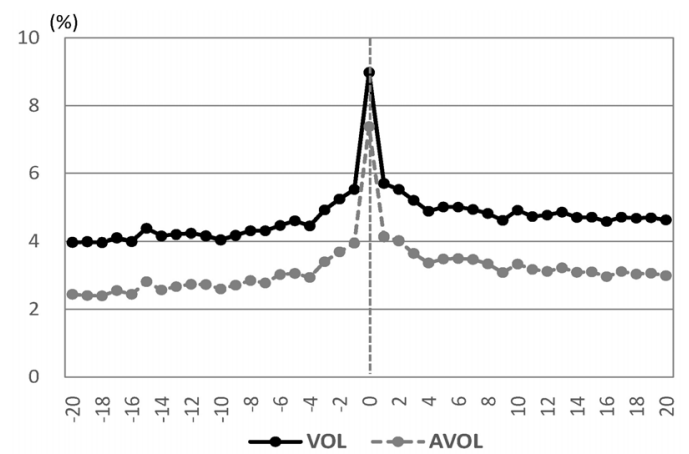

패널 B: 유형 2

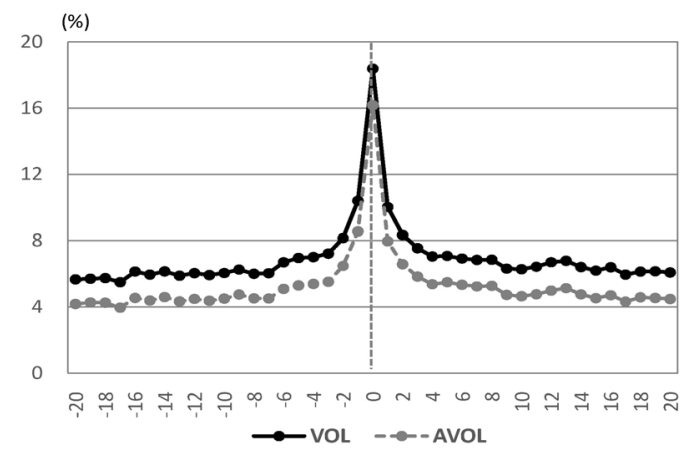


한국증권학회지 제49권 5호 (2020)

〈표 8〉 과열 종목 지정 전 · 후 변동성과 초과변동성의 기간 차이 검정

2017년 9월 25일부터 2019년 10월 31일까지 공매도 과열종목 지정 전 기간 $(-20,0)$ 과 지정 후 기간 $(1,20)$ 의 일별 변동성 $(V O L)$ 과 초과변동성 $(A V O L)$ 의 표본 평균 차이에 대한 검정결과이다. 첫 번째 값은 평균, 두 번째 괄호안의 값은 $\mathrm{t}$ 통계치, 세 번째 각괄호안의 값은 비모수검정의 유의확률( $\left.\mathrm{p}^{-} \mathrm{value}\right)$ 이다. 네 번째 $H_{A}: \mu_{\text {pre }} \neq \mu_{\text {post }}$ 는 각 유형별 개별 표본의 평균 차이에 대한 비모수검정에서 $5 \%$ 수준에서 유의적인 표본의 비율 $(\%)$ 이며, $\%\left(\mu_{p r e}<\mu_{p o s t}\right)$ 는 각 유형별 개별 표본의 지정 후 기간의 평균이 지정 전 기간의 평균보다 큰 표본의 비율(\%)이다. * ${ }^{* *},{ }^{* * *}$ 는 각각 $10 \%, 5 \%, 1 \%$ 수준에서 유의적이다.

\begin{tabular}{|c|c|c|c|c|c|c|c|c|}
\hline \multirow[t]{2}{*}{ 시장구분 } & \multirow{2}{*}{$\begin{array}{l}\text { 지정 } \\
\text { 유형 }\end{array}$} & \multirow[t]{2}{*}{ 통계치 } & \multicolumn{2}{|c|}{$\begin{array}{l}\text { 지정 전 기간 } \\
\text { (pre period) }\end{array}$} & \multicolumn{2}{|c|}{$\begin{array}{l}\text { 지정 후 기간 } \\
\text { (post period) }\end{array}$} & \multicolumn{2}{|c|}{$\begin{array}{l}\text { 차이 검정 } \\
\text { (post-pre) }\end{array}$} \\
\hline & & & 변동성 & 초과변동성 & 변동성 & 초과변동성 & 변동성 & 초과변동성 \\
\hline \multirow{12}{*}{$\begin{array}{l}\text { 유가증권 } \\
\quad(\%)\end{array}$} & \multirow[t]{4}{*}{1} & \multirow{2}{*}{$\begin{array}{l}\text { 평균 } \\
\mathrm{t} \text {-통계치 } \\
\text { 비모수p-val }\end{array}$} & $\begin{array}{c}3.51 \\
(3351)^{* * * *}\end{array}$ & $\begin{array}{c}2.48 \\
\left(2473^{* * * *}\right.\end{array}$ & $\begin{array}{c}3.52 \\
(210)^{* * *}\end{array}$ & $\frac{2.47}{(23)^{* * * *}}$ & 0.01 & $\begin{array}{r}-0.01 \\
\end{array}$ \\
\hline & & & [0.000] & {$[0.000]$} & [0.000] & [0.000] & [0.865] & {$[0.954]$} \\
\hline & & \multirow{2}{*}{$\begin{array}{l}H_{A}: \mu_{\text {pre }} \neq \mu_{\text {post }} \\
\%\left(\mu_{\text {pre }}<\mu_{\text {post }}\right)\end{array}$} & & & & & 29.79 & 23.40 \\
\hline & & & & & & & 48.94 & 45.74 \\
\hline & \multirow{5}{*}{2} & \multirow{8}{*}{$\begin{array}{l}\text { 평균 } \\
\mathrm{t}-\text { 통계치 } \\
\text { 비모수p-val } \\
H_{A}: \mu_{p r e} \neq \mu_{\text {post }} \\
\%\left(\mu_{\text {pre }}<\mu_{\text {post }}\right)\end{array}$} & 5.52 & 4.55 & 5.61 & 4.55 & 0.09 & 0.00 \\
\hline & & & $(30.03)^{* * * *}$ & $(24.81)^{* * * *}$ & $(25.54)^{* * * *}$ & $(21.02)^{* * * *}$ & $(0.33)$ & $(0.01)$ \\
\hline & & & {$[0.000]$} & {$[0.000]$} & {$[0.000]$} & {$[0.000]$} & [0.318] & [0.319] \\
\hline & & & & & & & 37.34 & 32.91 \\
\hline & & & & & & & 44.94 & 41.14 \\
\hline & \multirow{3}{*}{$\begin{array}{l}\text { 차이 } \\
(1-2)\end{array}$} & & -2.01 & -2.07 & -2.09 & -2.08 & -0.08 & -0.01 \\
\hline & & & $(-9.50)^{* * *}$ & $(-9.90)^{* * *}$ & $(-8.50)^{* * * *}$ & $(-8.63)^{* * * *}$ & $(-0.37)$ & $(-0.03)$ \\
\hline & & & {$[0.000]$} & {$[0.000]$} & {$[0.000]$} & {$[0.000]$} & [0.469] & {$[0.234]$} \\
\hline \multirow{24}{*}{$\begin{array}{r}\text { 코스닥 } \\
(\%)\end{array}$} & \multirow[t]{5}{*}{1} & \multirow{5}{*}{$\begin{array}{l}\text { 평균 } \\
\mathrm{t} \text {-통계치 } \\
\text { 비모수p-val } \\
H_{A}: \mu_{\text {pre }} \neq \mu_{\text {post }} \\
\%\left(\mu_{\text {pre }}<\mu_{\text {post }}\right)\end{array}$} & 4.67 & 3.07 & 4.63 & 2.92 & -0.04 & -0.15 \\
\hline & & & $(31.76)^{* * * *}$ & $(21.62)^{* * * *}$ & $(28.37)^{* * *}$ & $(18.63)^{* * * *}$ & $(-0.17)$ & $(-0.73)$ \\
\hline & & & {$[0.000]$} & {$[0.000]$} & {$[0.000]$} & {$[0.000]$} & {$[0.614]$} & [0.255] \\
\hline & & & & & & & 28.12 & 25.00 \\
\hline & & & & & & & 43.75 & 36.46 \\
\hline & \multirow[t]{5}{*}{2} & 평균 & 7.04 & 5.44 & 6.82 & 5.17 & -0.21 & -0.27 \\
\hline & & t-통계치 & $(58.98)^{* * *}$ & $(45.48)^{* * *}$ & $(51.51)^{* * *}$ & $(39.77)^{* * * *}$ & $(-1.22)$ & $(-1.54)$ \\
\hline & & 비모수p-val & {$[0.000]$} & {$[0.000]$} & {$[0.000]$} & {$[0.000]$} & {$[0.117]$} & {$[0.035]$} \\
\hline & & \multirow{2}{*}{$\begin{array}{l}H_{A}: \mu_{\text {pre }} \neq \mu_{\text {post }} \\
\%\left(\mu_{\text {pre }}<\mu_{\text {post }}\right)\end{array}$} & & & & & 35.59 & 30.79 \\
\hline & & & & & & & 42.36 & 39.96 \\
\hline & \multirow[t]{5}{*}{3} & \multirow{5}{*}{$\begin{array}{l}\text { 평균 } \\
\mathrm{t} \text {-통계치 } \\
\text { 비모수p-val } \\
H_{A}: \mu_{\text {pre }} \neq \mu_{\text {post }} \\
\%\left(\mu_{\text {pre }}<\mu_{\text {post }}\right)\end{array}$} & 4.57 & 3.05 & 4.88 & 3.31 & 0.30 & 0.26 \\
\hline & & & $(69.19)^{* * *}$ & $(46.62)^{* * * *}$ & $(57.28)^{* * *}$ & $(38.84)^{* * * *}$ & $(2.81)^{* * *}$ & $(2.41)^{* *}$ \\
\hline & & & {$[0.000]$} & {$[0.000]$} & {$[0.000]$} & {$[0.000]$} & [0.138] & [0.279] \\
\hline & & & & & & & 32.87 & 24.90 \\
\hline & & & & & & & 55.06 & 51.95 \\
\hline & \multirow{3}{*}{\multicolumn{2}{|c|}{$\begin{array}{l}\text { 차이 } \\
(1-2)\end{array}$}} & -2.37 & -2.36 & -2.18 & -2.25 & 0.17 & -0.11 \\
\hline & & & $(-12.50)^{* * *}$ & $(-12.75)^{* * *}$ & $(-10.40)^{* * *}$ & $(-11.07)^{* * *}$ & $(0.87)$ & $(-0.59)$ \\
\hline & & & {$[0.000]$} & {$[0.000]$} & [0.000] & {$[0.000]$} & {$[0.256]$} & [0.372] \\
\hline & \multicolumn{2}{|l|}{ 차이 } & 0.10 & 0.02 & -0.24 & -0.39 & -0.34 & -0.42 \\
\hline & \multirow{2}{*}{\multicolumn{2}{|c|}{$(1-3)$}} & $(0.61)$ & $(0.12)$ & $(-1.31)$ & $(-2.22)^{* *}$ & $(-1.88)^{*}$ & $(-2.56)^{* *}$ \\
\hline & & & [0.476] & [0.824] & [0.499] & [0.092] & [0.027] & [0.002] \\
\hline & \multirow{3}{*}{\multicolumn{2}{|c|}{$\begin{array}{l}\text { 차이 } \\
(2-3)\end{array}$}} & 2.47 & 2.38 & 1.94 & 1.86 & -0.51 & -0.52 \\
\hline & & & $(18.59)^{* * * *}$ & $(17.51)^{* * * *}$ & $(12.36)^{* * * *}$ & $(11.94)^{* * * *}$ & $(-3.64)^{* * * *}$ & $(-3.90)^{* * *}$ \\
\hline & & & {$[0.000]$} & {$[0.000]$} & {$[0.000]$} & {$[0.000]$} & {$[0.000]$} & {$[0.000]$} \\
\hline
\end{tabular}


The Effect of KRX Halts on Overheated Short-selling Stocks

나타났다. 유형 3 의 $A V O L$ 은 유형 1 과 2와 달리, 지정 후 기간의 일평균은 $3.31 \%$ 로 지정 전 기간에 비해 $0.26 \%$ 포인트 증가했으며, t검정에서 $5 \%$ 수준에서 유의적으로 나타났다. 그러나 지정 전 기간동안 변동성이 가장 높은 지정일의 $A V O L$ 인 $7.38 \%$ 에 비해서는 현저히 감소한 수치이므로, 노이즈 거래에 기인할 수 있는 변동성이 감소하는 결과를 제시한다. 이는 <표 $8>$ 에 제시된 변동성의 결과로 볼 때 급격한 가격변동과 정보비대칭을 완화시키는 제도 실행의 목적에 부합하는 것으로 평가할 수 있다.

이제 유가증권시장과 코스닥의 개별 표본에 대해 지정 전·후기간 변동성 지표의 차이에 대한 비모수적 통계적 유의성이 검증된 비율과 지정 후 기간이 지정 전 기간보다 증가한 비율을 보도록 하자. 양 기간의 $V O L$ 의 평균이 동일하다는 귀무가설을 기각한 표본비율은 $28.12 \%$ (코스닥 유형 1)부터 37.34\%(유가증권 유형 2)까지 분포하여 이는 상대적으로 양 기간의 평균이 동일함이 지배적인 특성임을 제시한다. $A V O L$ 도 $V O L$ 과 같이 양 기간의 평균이 동일하다는 귀무가설을 기각한 표본비율은 $23.40 \%$ 32.91\%로 제한적인 범위에 그쳐, 상대적으로 양 기간의 평균차이가 비유의적인 표본이 지배적임을 의미한다. 또한 개별 표본에 대해 지정 후 기간의 일평균이 지정 전 기간의 일평균보다 증가한 표본의 비율은 코스닥의 유형 3 을 제외한 표본들에서 변동성과 초과변동성에서 $50 \%$ 미만으로 집계되어 과열 종목에 대한 지정은 그 후 기간의 변동성을 완화시키는 효과를 지지한다.

제한된 지면 때문에 별도의 분석 결과로 제시하지 않았지만, 사건기간 설정이 미치는 효과의 강건성 검정 목적으로 기본 분석의 지정 전 기간과 지정 후 기간인 20 일 대신 <표 $7>$ 과 같이 10 일부터 30 일까지 적용하여 분석 결과에 미치는 효과를 검토했다. 사건기간이 길어질수록, 유가증권시장과 코스닥의 변동성 지표들은 감소하는 패턴이 관찰되었으나 지정 후 기간의 감소 추세는 상대적으로 지정 전 기간 감소 추세보다 완화되는 패턴을 보였다. 그럼에도 불구하고, 분석 결과는 <표 8>과 수치에서만 차이가 있지만 통계적 유의성에서는 큰 차이가 없이 일관성 있는 결과를 보였다. 또한 제 2 장의 방법론에서 언급한 대안적인 변동성 지표로 사건기간동안 개별종목 수익률의 표준편차로 측정한 원측정치와 이로부터 시장수익률의 표준편차를 차감한 초과측정치로도 실증분석을 수행한 결과에서도 모든 유형에서 지정 후 기간의 변동성은 지정 전 기간에 비해 유의적으로 감소했음을 확인할 수 있었다.

\subsection{3 공매도거래비율}

$<$ 그림 7>에서 유가증권시장의 지정 유형별 공매도거래비율의 행태를 보도록 하자. 패널 $\mathrm{A}$ 와 패널 $\mathrm{B}$ 의 좌측 그래프인 공매도거래비율에서 관찰되는 공통된 특징은 지정일 $(\mathrm{t}=0)$ 에서 $S T R$ 과 $A S T R$ 은 급등하며, 다음날은 공매도 중단일이므로 $A S T R$ 가 음이지만, 중단일 다음날 $(t=2)$ 에는 재상승하는 행태를 보인다. 이같이 중단일 다음날 $A S T R$ 이 재상승한 원인은 공매도 중단일의 공매도가 다음날에 집중되기 때문이다. 지정 후 $S T R$ 과 $A S T R$ 은 $t=3$ 일 이후부터 20 일까지 감소추세가 지속된다. 사건기간동안 유형 1 의 $A S T R$ 는 유형 2 의 $A S T R$ 보다 높은데 이는 공매도 과열 종목 지정 기준에서 유형 1 에 공매도거래비율이 포함되어 있기 때문이다. 특히 유형 2 의 $A S T R$ 은 과열종목 지정일을 제외한 거래일에서는 음의 수치로 나타나, 이는 
한국증권학회지 제49권 5호 (2020)

$S T R$ 이 시장평균 공매도거래비율보다 낮은 수준임을 의미한다. 지정일 당일의 유형 1 의 $A S T R_{0}$ 은 $19.81 \%$ 로 가장 높으며, 유형 2 의 $A S T R_{0}$ 은 $0.06 \%$ 에 불과했다.

<그림 8>에는 코스닥시장의 지정 유형별 공매도거래비율 $(S T R)$ 과 초과공매도거래비율의 지정일 전·후 기간의 행태가 제시된다. 각 패널의 그래프에서 지정일 $(t=0)$ 에 $S T R$ 과 $A S T R$ 은 급등하지만, 다음날인 공매도 중단일에 $A S T R$ 가 음으로 하락하며 중단일 다음날 $(t=2)$ 에 지정일 보다는 적은 비율로 재상승하는 행태는 유가증권시장과 역시 유사하다. 지정일의 유형 1 의 $A S T R_{0}$ 은 $19.14 \%$ 이며, 유형 2의 $A S T R_{0}$ 은 $0.50 \%$ 에 불과했다. 공매도 거래대금 증가율과 공매도 비중 평균이 지정 기준 요소인 유형 3 의 $A S T R_{0}$ 은 $13.89 \%$ 로 유형 2 보다 높았다.

<표 9>는 <그림 8>에서 검토한 공매도거래비율의 행태에 대해 과열종목 지정 전. 후 기간동안 공매도거래비율의 통계적 차이를 검증한다. 공매도거래비율의 분석결과는 초과공매도거래 비율과 질적으로 차이가 없으므로, $A S T R$ 를 중심으로 설명한다. 상단의 유가증권시장의 유형 1 에서 지정 전 기간의 $A S T R$ 은 $4.06 \%$ 로 $\mathrm{t}$-검정과 비모수검정에서 모두 $1 \%$ 수준에서 유의적이며 지정 후 기간의 $\overline{A S T R_{[1,20]}}$ 은 $4.54 \%$ 로 역시 $1 \%$ 수준에서 유의적이다. 그러나 기간의 평균 차이는 $0.48 \% \mathrm{p}$ 로 유의성을 발견할 수 없어 지정 후의 공매도 행태는 지정 전 기간에 비해 구조적 변화가 없음을 시사한다. 유형 2에서 $A S T R$ 은 지정 전·후 기간에서 모두 음의 값으로, 시장평균 공매도거래비율보다 낮은 표본들로 구성된 특성을 보인다. 지정 전·후 기간의 $A S T R$ 은 $-2.35 \%$ 에서 $-2.10 \%$ 로 $0.25 \% \mathrm{p}$ 상승했으나, 유형 1 과 같이 유의성이 존재하지 않아 지정 후의 공매도 행태는 지정 전과 대비하여 유의적 변동이 없다. 또한 각 유형의 기간 차이(post-pre)에 대한 유형간 차이(1-2)의 평균치는 $0.23 \%$ 포인트로 통계적 유의성을 발견할 수 없어 지정 제도는 각 유형에 동일한 효과를 가져온 것으로 평가한다. 이같은 결과는 지정 전 이상 공매도로 의심되는 공매도를 매매중단으로 차단하여 사후적으로 발생가능한 불공정거래 행위를 완화하는 효과에 부합한다고 평가된다.

코스닥시장에서 유형 1 은 유가증권시장의 유형 1 과 같이 지정 후 기간의 $\overline{A S T R}_{[1,20]}$ 의 평균치는 $4.86 \%$ 로 지정 전 기간의 평균치 대비 $0.35 \%$ 포인트 증가했지만 그 차이에서 통계적 유의성은 발견되지 않아, 과열 종목 지정 전 공매도 행태가 지정 후에도 지속되는 경향으로 해석할 수 있다. 유형 2 의 $A S T R$ 도 유가증권시장과 같이 지정 전·후 기간에서 통계적으로 유의적인 음의 값이지만, 지정 전 기간 대비 $0.20 \%$ 증가했다. $\mathrm{t}$ 검정에서는 유의성이 발견되지 않았지만, 비모수검정에서는 $5 \%$ 수준에서 전·후 기간이 동일하다는 귀무가설을 기각했다. 그러나 지정 후 기간의 $\overline{A S T R}_{[1,20]}$ 인 $-0.68 \%$ 는 지정일의 $A S T R_{0}$ 인 $0.50 \%$ 보다 하락하고 시장평균공매거래 수준을 하회하므로 과열 상태가 진정되었다고 평가할 수 있다.

유형 1 과 유형 2 와 달리 유형 3 의 지정 후 기간의 $A S T R$ 은 $4.34 \%$ 로 지정 전 기간의 일평균에 비해 $1 \% \mathrm{p}$ 감소했으며, 기간의 차이도 $1 \%$ 수준에서 통계적으로 유의적이다. 이같은 결과는 $<$ 그림 3>과 <그림 $4>$, 그리고 <표 6>에서 제시된 주가상승 억제에 따라 추종할 공매도 물량이 감소하는 현상으로 해석할 수 있다. 코스닥시장에서 유형별 기간 차이에 대한 유형 1 과 유형 2 의 차이는 $0.15 \%$ 포인트로 유가증권시장의 유형 1 과 유형 2 간 차이에 대한 통계적 유의성이 
The Effect of KRX Halts on Overheated Short-selling Stocks

〈그림 7〉 유가증권시장 공매도 과열종목 지정 전 · 후 유형별 공매도거래비율과 초과 공매도거래비율 2017년 9월 25일부터 2019년 10월 31일까지 유가증권시장의 공매도 과열종목 지정일 기준으로 전 기간 $(-20,0)$ 과 지정 후 기간 $(1,20)$ 의 지정유형별 공매도거래비율 $(S T R)$ 과 초과공매도거래비율 $(A S T R)$ 이다.

\section{패널 $\mathrm{A}:$ 유형 1}

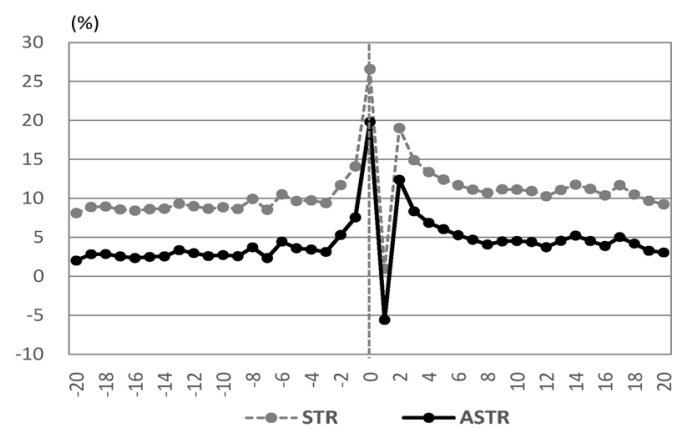

패널 $\mathrm{B}:$ 유형 2

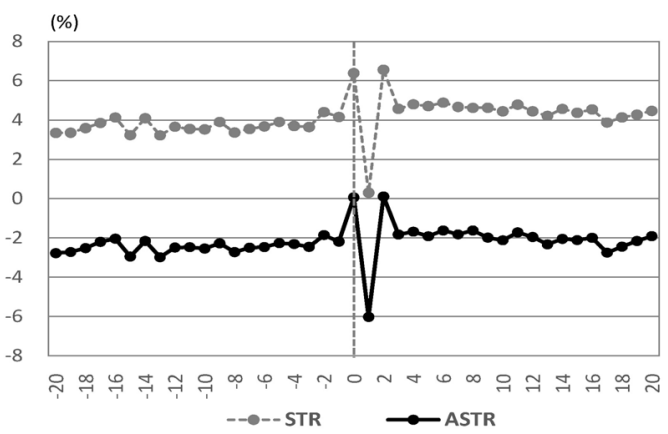

〈그림 8〉 코스닥 공매도 과열종목 지정 전 - 후 유형별 공매도거래비율과 초과공매도거래비율 2017년 9월 25일부터 2019년 10월 31일까지 코스닥시장의 공매도 과열종목 지정일 기준으로 전 기간 $(-20,0)$ 과 지정 후 기간 $(1,20)$ 의 지정유형별 공매도거래비율 $(S T R)$ 과 초과공매도거래비율 $(A S T R)$ 이다.

패널 $\mathrm{A}$ : 유형 1

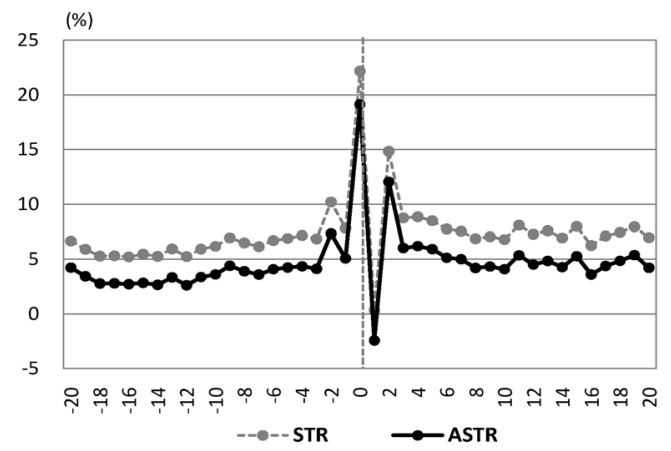

패널 $\mathrm{C}:$ 유형 3

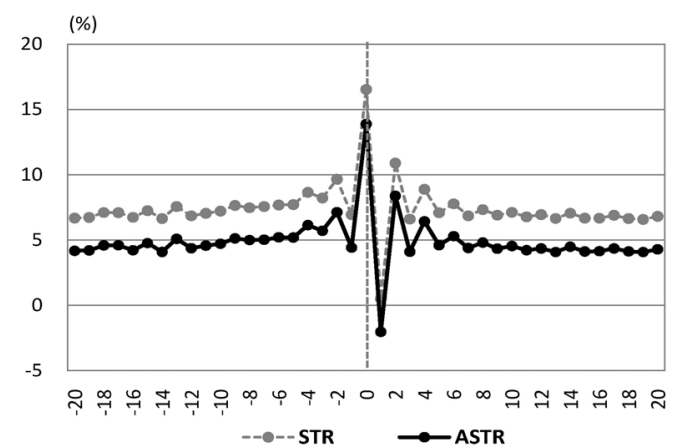

패널 $\mathrm{B}:$ 유형 2

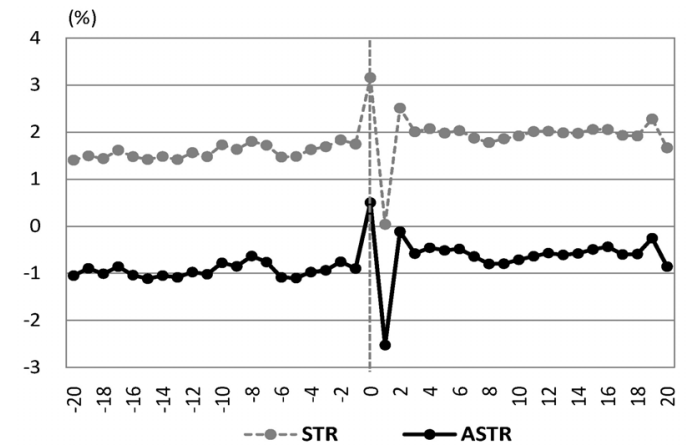


〈표 9〉 과열 종목 지정 전 · 후 공매도거래비율과 초과공매도거래비율

2017년 9월 25일부터 2019년 10월 31일까지 공매도 과열종목 지정 전 기간 $(-20,0)$ 과 지정 후 기간 $(1,20)$ 의 일별 공매도거래비율 $(S T R)$ 과 초과공매도거래비율 $(A S T R)$ 의 표본 평균 차이에 대한 검정결과이다. 첫 번째 값은 평균, 두 번째 괄호안의 값은 $\mathrm{t}$ 통계치, 세 번째 각괄호안의 값은 비모수검정의 유의확률 $\left(\mathrm{p}^{-} \mathrm{val}-\right.$ $\mathrm{ue}$ )이다. 네 번째 $H_{A}: \mu_{\text {pre }} \neq \mu_{\text {post }}$ 는 각 유형별 개별 표본의 평균 차이에 대한 비모수검정에서 $5 \%$ 수준에서 유의적인 표본의 비율이며, $\%\left(\mu_{p r e}<\mu_{p o s t}\right)$ 는 각 유형별 개별 표본의 지정 후 기간의 평균이 지정 전 기간의 평균보다 큰 표본의 비율이다. ${ }^{*},{ }^{* *},{ }^{* * *}$ 는 각각 $10 \%, 5 \%, 1 \%$ 수준에서 유의적이다.

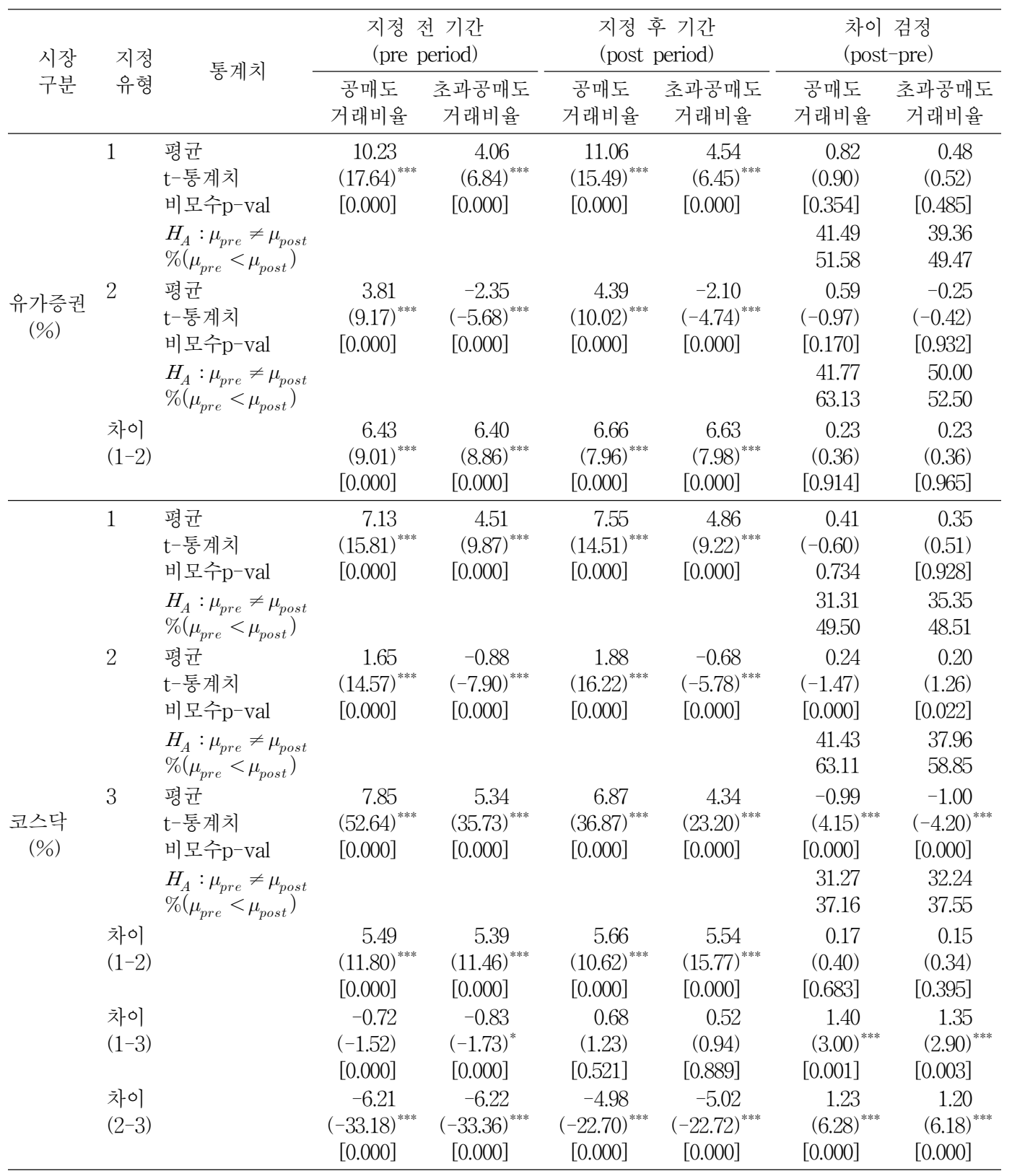


The Effect of KRX Halts on Overheated Short-selling Stocks

없다는 특성과 일관성을 유사하다. 반면에 유형 3 의 $A S T R$ 은 지정 후 기간에 유의적으로 감소했으므로 기간간 차이에 대한 유형 1 과 유형 3 의 차이, 유형 2 와 유형 3 의 차이는 $1 \%$ 수준에서 유의적이다. 이상의 결과를 종합하면, 과열종목 지정 후에도 공매도 행태가 유의적으로 증가한 유형은 없으므로 투기적 목적의 추종 공매도 억제라는 제도의 기본적 기능이 작동한 것으로 평가한다.

이제 유가증권시장과 코스닥시장의 개별 표본에 대해 지정 전·후기간 공매도거래비율 지표의 차이에 대한 비모수적 통계적 유의성이 확인된 비율과 지정 후 기간이 지정 전 기간보다 증가한 비율을 보도록 한다. $S T R$ 의 양 기간의 평균이 동일하다는 귀무가설을 $5 \%$ 유의수준에서 기각한 표본비율은 31.27\%(코스닥 유형 3)부터 41.77\%(유가증권 유형 2)까지 분포하여, 개별 표본 수준에서도 양 기간의 공매도거래비율의 평균은 통계적으로 차이가 없다는 표본의 지배적 특성을 보여준다. $A S T R$ 도 유가증권시장의 유형 2 를 제외한 각 유형에서 양 기간의 평균이 동일하다는 귀무가설을 기각한 표본비율은 $40 \%$ 미만으로, $S T R$ 과 일관성있게 공매도 중단 후 과열종목의 시장수준을 초과하는 공매도거래가 지정 전 기간 수준으로 제어되었다는 증거를 제시한다.

제약된 지면 관계로 별도의 분석 결과로 제시하지 않았지만, 강건성 검정 차원에서 기본 분석에서 설정한 지정 전 기간과 지정 후 기간인 20 일 대신 <표 $7>$ 과 같이 10 일부터 30 일까지 적용하여 사건기간 설정이 분석 결과에 미치는 영향을 검토했다. 유가증권시장과 코스닥의 공매거래비율 지표들은 사건기간일 설정에 따라 수치에서는 차이가 있었지만, 양 기간간 차이에 대한 통계적 유의성을 보면 <표 9>에 제시된 각 시장의 유형에서 확인된 결과와 일관성을 유지했다. 즉, 코스닥의 유형 3 에서만 지정 전 기간의 $S T R$ 과 $A S T R$ 는 지정 후 기간보다 $1 \%$ 수준에서 유의적으로 감소했을 뿐, 다른 유형에서는 지정 전 기간과 지정 후 기간의 차이에 대해서는 유의성을 발견할 수 없었다. 따라서 과열종목이라는 신호의 정보효과가 지속가능 기간을 고려할 때 과열종목 지정 후에도 공매도가 유의적으로 증가한 유형은 없으므로 투기적 목적의 추종 공매도를 제어한다는 제도의 기본적 기능이 작동한 것으로 평가한다.

\section{5 추가분석 결과}

\subsection{1 과열종목 지정제도 시행 전 기간의 유사 표본과 비교}

제 4 절까지의 내용들의 분석의 틀은 지정이 발동된 표본들에 대해 지정 사건의 평균적 효과를 파악하는 목적으로 설계되었다. 그러나, 이러한 지정 사건의 효과가 지지되기 위해서는 공매도 과열 종목 지정제도의 도입의 실효성도 파악되어야 한다. 이는 제도가 도입되기 전 기간에서 지정 요인과 동일한 조건에 해당하는 표본을 '유사 표본(quasi sample)'으로 선정하여, 표본기간의 분석 결과와 비교하여 검증할 수 있다. 즉, 과열 종목으로 지정된 '원표본(original sample)'과 조건이 동일하지만 지정이라는 사건이 없는 유사 표본을 대상으로 동일한 분석을 수행하여 사건의 효과를 분석하는 것이다. 추가분석에서는 공매도 과열종목 지정제도가 도입되기 전인 2016년 4월 1일부터 2017년 3월 26일까지기간 243거래일동안 유사 표본에 대해 주가변동 행태를 
한국증권학회지 제49권 5호 (2020)

중점적으로 분석한다.16) <표 10>과 <그림 9>에서는 유사 표본들에 대해 과열종목 지정 요건들을 충족하는 '사건'을 기준으로 20 일 전·후 기간의 누적수익률과 누적초과수익률을 보여준다. 사건 이전 기간은 사건에 해당하는 거래일을 포함하여 21 일 전 기간, 그리고 사건 후 기간은 사건일 다음날부터 20 일동안의 기간으로 원표본의 사건 기간과 동일하다.

〈표 10〉제도 도입 전 공매도 과열 유사 표본의 사건 전·후 누적수익률과 누적초과수익률 2016년 4월 1일부터 2017년 3월 26일까지 기간동안 공매도 과열 종목과 동일한 조건에 해당하는 유사 표본에 대해 과열 종목 지정 요건이 발생한 사건 이전 기간 $(-20,0)$ 과 사건 후 기간 $(1,20)$ 의 누적수익률 $(C R)$ 과 누적초과수익률 $(C A R)$ 의 표본 평균 차이에 대한 검정결과이다. 첫 번째 값은 평균, 두 번째 괄호안의 값은 $\mathrm{t}$ 통계치, 세 번째 각괄호안의 값은 비모수검정의 유의확률(p-value)이다. ${ }^{*},{ }^{* *},{ }^{* * *}$ 는 각각 $10 \%$, $5 \%, 1 \%$ 수준에서 유의적이다.

\begin{tabular}{|c|c|c|c|c|c|c|c|}
\hline \multirow{2}{*}{ 시장구분 } & \multirow{2}{*}{$\begin{array}{c}\text { 지정유형 } \\
\text { (유사 표본수) }\end{array}$} & \multicolumn{2}{|c|}{$\begin{array}{c}\text { 지정 전 기간 } \\
\text { (pre period) }\end{array}$} & \multicolumn{2}{|c|}{$\begin{array}{l}\text { 지정 후 기간 } \\
\text { (post period) }\end{array}$} & \multicolumn{2}{|c|}{$\begin{array}{l}\text { 차이 검정 } \\
\text { (post-pre) }\end{array}$} \\
\hline & & 수익률 & 초과수익률 & 수익률 & 초과수익률 & 수익률 & 초과수익률 \\
\hline \multirow{6}{*}{$\begin{array}{c}\text { 유가증권 } \\
(\%)\end{array}$} & \multirow{3}{*}{$\begin{array}{l}1 \\
(19)\end{array}$} & -2.27 & -2.67 & -3.94 & -4.61 & -1.67 & -1.94 \\
\hline & & $(-1.19)$ & $(-1.49)$ & $(-2.05)^{*}$ & $(-2.57)^{* *}$ & $(-0.62)$ & $(-0.77)$ \\
\hline & & [0.196] & [0.087] & [0.049] & {$[0.026]$} & {$[0.511]$} & [0.357] \\
\hline & \multirow{3}{*}{$\begin{array}{l}2 \\
(53)\end{array}$} & 3.73 & 3.45 & -5.64 & -5.62 & -9.37 & -9.09 \\
\hline & & $(0.88)$ & $(0.83)$ & $(-2.51)^{* * * *}$ & $(-2.51)^{* * * *}$ & $(1.96)^{*}$ & $(1.91)^{*}$ \\
\hline & & [0.678] & [0.763] & [0.003] & {$[0.001]$} & [0.196] & [0.209] \\
\hline \multirow{6}{*}{$\begin{array}{c}\text { 코스닥 } \\
(\%)\end{array}$} & \multirow{3}{*}{$\begin{array}{l}2 \\
(147)\end{array}$} & -1.15 & 1.06 & -2.38 & -1.28 & -1.23 & -2.34 \\
\hline & & $(-0.48)$ & $(0.45)$ & $(-1.63)$ & $(-0.93)$ & $(-0.66)$ & $(-0.38)$ \\
\hline & & [0.949] & [0.189] & {$[0.010]$} & {$[0.060]$} & {$[0.364]$} & [0.119] \\
\hline & \multirow{3}{*}{$\begin{array}{l}3 \\
(161)\end{array}$} & -0.85 & 0.47 & -3.86 & -2.86 & -3.01 & -3.33 \\
\hline & & $(-0.79)$ & $(0.44)$ & $(-3.94)^{* * * *}$ & $(-3.02)^{* * *}$ & $(2.06)^{* *}$ & $(2.34)^{* *}$ \\
\hline & & {$[0.000]$} & {$[0.003]$} & {$[0.000]$} & {$[0.000]$} & {$[0.272]$} & [0.113] \\
\hline
\end{tabular}

유가증권시장에서 유형 1 과 유형 2 로 분류된 유사 표본들의 수는 각각 19 건과 53 건로 집계되었다. <표 10>에서 유형 1에서 사건 이전 기간의 $C A R$ 는 $-2.67 \%$ 로 <표 6>의 지정 전 기간의 수치의 절대값보다 적은 반면, 사건 후 기간의 $C A R$ 는 $-4.61 \%$ 으로, $5 \%$ 수준에서 유의적이며 크다. 사건 전·후 기간의 $C A R$ 의 차이에서는 유의성은 발견되지 않았지만, <표 $6>$ 과 <그림 3>의 패널 $\mathrm{A}$ 를 <그림 9>와 비교할 때 유사 표본에서는 사건 이전 기간의 추세가 사건 후에도 지속됨이 확인된다. 유형 2에서는 사건 후 기간의 $C A R$ 가 $-5.62 \%$ 로 $1 \%$ 수준에서 강한 유의성이 나타난 결과는 <표 $6>$ 의 원표본의 유형 2 의 지정 후 기간의 $C A R$ 의 수치와

16) 유사 표본을 선정한 기간이 표본 기간보다 짧은 이유는 <표 $1>$ 에서 코스닥시장에서 지정 유형 1 에서 시장 공매도의 수준을 측정하기 위한 코스닥 150 종목의 공매도 자료가 2016년 1월부터 집계되었으며, 유형 1 의 조건을 공매도 전분기의 비중을 근거로 계산하기 때문이다. 따라서 유사 표본은 2016년 2분기가 시작되는 4월 1일부터 선정 가능하다. 유사 표본을 대상으로 변동성과 회전율을 수행한 결과는 제4절의 분석 결과와 질적으로 동일한 것으로 해석되었으며, 방대한 지면을 절약하고자 주가변동을 중심으로 설명한다. 물론, 변동성과 회전율의 분석 결과를 확인하고자 하는 독자들의 요청이 있다면 전달할 수 있다. 
The Effect of KRX Halts on Overheated Short-selling Stocks

대비된다. <그림 3>과 <그림 9>의 패널 $\mathrm{A}$ 를 비교하면, 유사 표본에서는 사건일의 주가가 큰 폭으로 하락한 후에도 추가적으로 하락하는 경향이 지속됨을 보여준다. 따라서 유가증권시장 에서 유형 1 과 유형 2 에 해당하는 유사 표본의 사건 후의 주가변동과 통계적 유의성에 근거할 때 과열종목 지정은 추가적인 주가 하락을 제한하여 공매도 거래자들의 사건 후에 취할 수 있는 이익 실현 가능성을 낮춘다고 볼 수 있다.

코스닥시장에서는 유형 1 에 해당하는 유사 표본은 6 건에 불과하여 원표본의 규모와 차이가 크므로 분석 결과의 신뢰성을 담보할 수 없어 생략한다. 코스닥시장에서 유형 2 와 3 의 유사

〈그림 9> 제도 도입 전 공매도 과열 유사 표본의 사건 전 · 후 누적수익률과 누적초과수익률 2017년 9월 25일부터 2019년 10월 31일까지 기간동안 유가증권시장(패널 A)와 코스닥시장(패널 B)의 공매도 과열 종목과 동일한 조건에 해당하는 유사 표본에 대해 과열 종목 지정 요건이 발생한 사건 이전 기간 $(-20,0)$ 과 지정 후 기간 $(1,20)$ 의 지정유형별 누적수익률 $(C R)$ 과 누적초과수익률 $(C A R)$ 이다.

패널 $\mathrm{A}$ : 유가증권시장

유형 1

(\%)

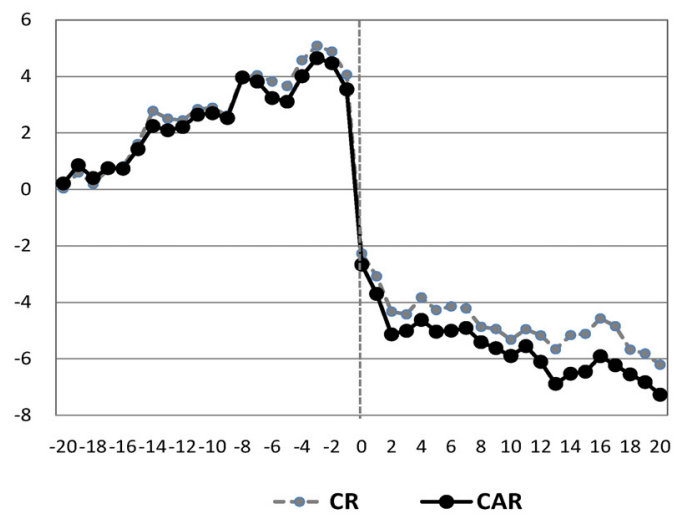

패널 $\mathrm{B}$ : 코스닥시장

유형 2

(\%)

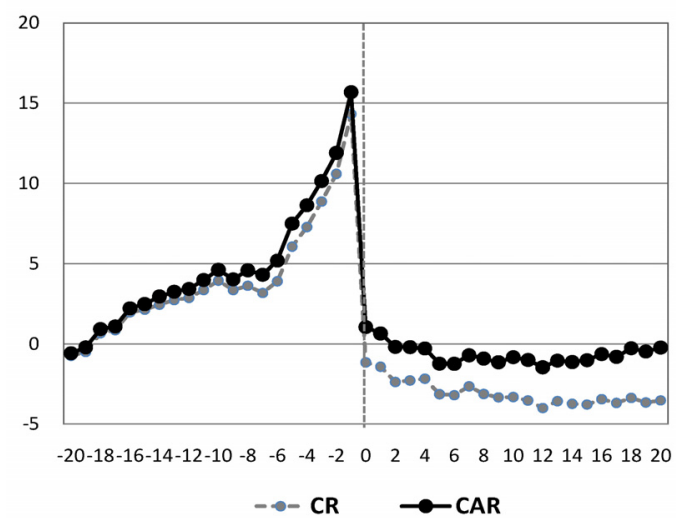

유형 2

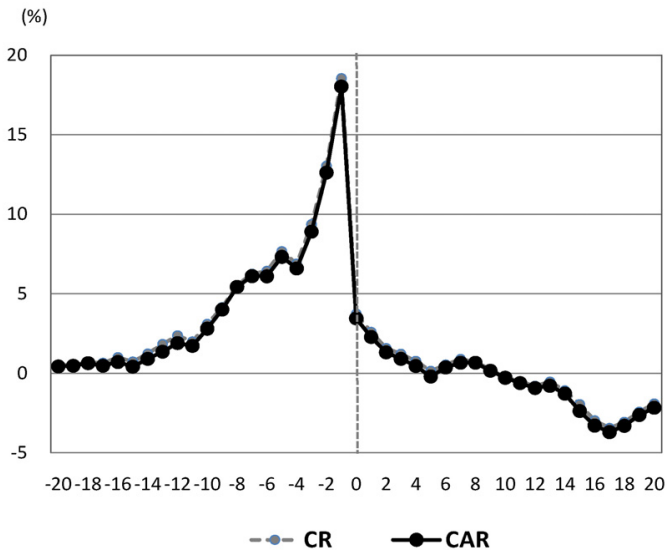

유형 3

(\%)

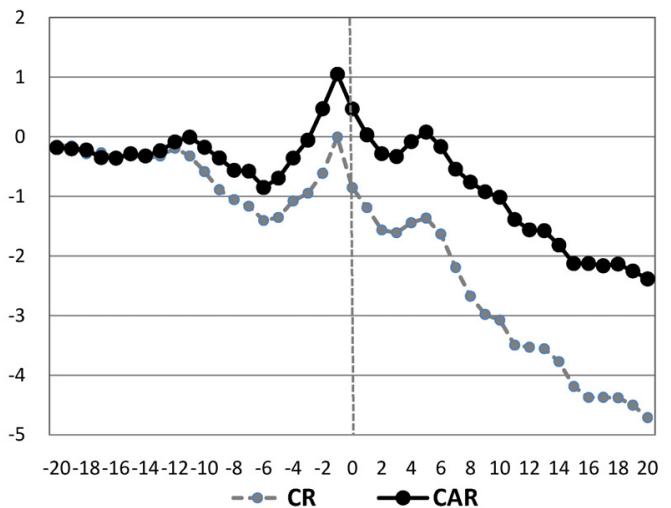


한국증권학회지 제49권 5호 (2020)

표본은 각각 147 건과 161 건으로, <표 $3>$ 의 코스닥시장의 종목 지정 분포의 패턴과 같이 유형 3 의 빈도가 높다. <표 $10>$ 에서 유형 2 의 사건 후 기간의 $C A R$ 는 사건 이전 기간에 비해 감소했지만 t검정 결과 5\% 수준에서 통계적 유의성을 발견할 수 없었으며, 기간간 차이에서도 유의성을 확인하지 못한 결과는 <표 $6>$ 의 결과와 수치는 다르지만 질적으로는 양립한다. 또한 <그림 $9>$ 의 패널 $\mathrm{B}$ 의 유형 2 에서도 사건 후의 패턴은 <그림 $4>$ 와 유사하다.

유형 3 에 해당하는 유사 기간의 사건 후 기간의 $C A R$ 는 $-2.86 \%$ 로 t검정이나 비모수검정에서 모두 $1 \%$ 수준에서 유의적으로 분석되어, 원표본의 지정 후 기간의 $C A R$ 보다 수치의 크기와 통계적 유의성에서 강하다. <그림 $9>$ 의 패널 $\mathrm{B}$ 에서 유사 표본의 사건 후 기간의 주가의 큰폭의 하락 추세가 지속되는 경향도 관찰된다. 따라서 유형 3 의 유사 표본에서 공매도가 과열된 수준 후의 가격 하락 추세로 볼 때, 공매도 과열이라는 신호가 시장에 전달되어 공매도로 인한 주가 하락을 방지하는 순기능을 가진 결과를 <그림 $4>$ 로 평가할 수 있다. 이상의 결과를 전반적으로 종합한다면, 공매도 과열 종목 지정 제도 도입은 공매도 행태의 변동을 초래했으며, 공매도 거래자가 주가 하락을 이용하여 시장에서 이익을 실현할 수 있는 기회를 방지하는 효과가 나타났음이 확인된다.

\subsection{2 과열종목 지정 후 기간의 추종 공매도의 수익성 분석}

제4절에서 공매도 과열 지정일 전후 행태를 제시한 <그림 $7>$ 과 <그림 8>에서는 공매도 중지일 후 공매도가 재개된 날 $(t=2)$ 에는 공매도가 일시적으로 증가한 현상이 확인되었다. 이와 같은 현상은 공매도의 일시적 중단으로 제약되었던 공매도 수요가 재개에 따라 증폭되었기 때문으로 해석할 수 있다. 만일 공매도 중지일 후 공매도 거래자들이 과열지정 전의 공매도 행태를 후속적으로 추종하여 단기적 이익을 얻으려 해도, 과열종목 지정의 신호가 시장에 전달된다면 추종 공매도 전략은 유의적인 이익을 실현할 수 없을 것이다. 즉, 공매도 과열 종목 지정으로 인해 공매도의 추가적 유입에서 솟커버링(short covering)으로 전환하여 가격이 반전한다면 과열 종목 지정 후 공매도를 추종하여 취할 수 있는 이익 기회는 소멸되므로 이는 공매도 과열종목 지정의 효과로 평가될 수 있다.

<표 11>은 공매도 후 숏커버링의 매매차익에 기반한 공매도전략의 성과를 제시한다. 본 연구의 자료는 개별 계좌자료가 아닌 일별-종목별 자료이므로 거래일의 투자자가 공매도한 종목의 평균가격이 숏커버링에 해당하는 매수평균가격을 초과하여 매매수수료율과 거래세율, 그리고 시장수익률을 고려하고도 이익이 발생하는지를 식 (3)으로 측정했으며, 이는 중단일 다음날 $(t=2)$ 에 공매도거래량가중평균가격(avgssprc)으로 매도한 후 그날을 포함하여 10일까지 솟커버링가격인 거래량가중평균가격(avgprc)의 초과수익률이다.17) 10 일의 기간은 Wang et al.(2017)의 연구에서 공매도부터 정산까지의 과정의 $44 \%$ 가 일중 내에 이루어지며, 5 거래일 내에 완료되는 비중은 $76 \%$ 로 분석된 결과를 근거로 공매도 거래자들의 단기투자기간을 고려한

17) 해당 종목의 avgssprc은 공매도대금을 공매도수량으로 나눈 값이며, avgprc은 거래대금을 거래량으로 나눈 값이다. 원공매도 물량에 대응되는 솟커버링 가격은 자료의 특성상 파악할 수 없으므로, 거래일의 매수평균가격으로 간주한 것이다. 
The Effect of KRX Halts on Overheated Short-selling Stocks

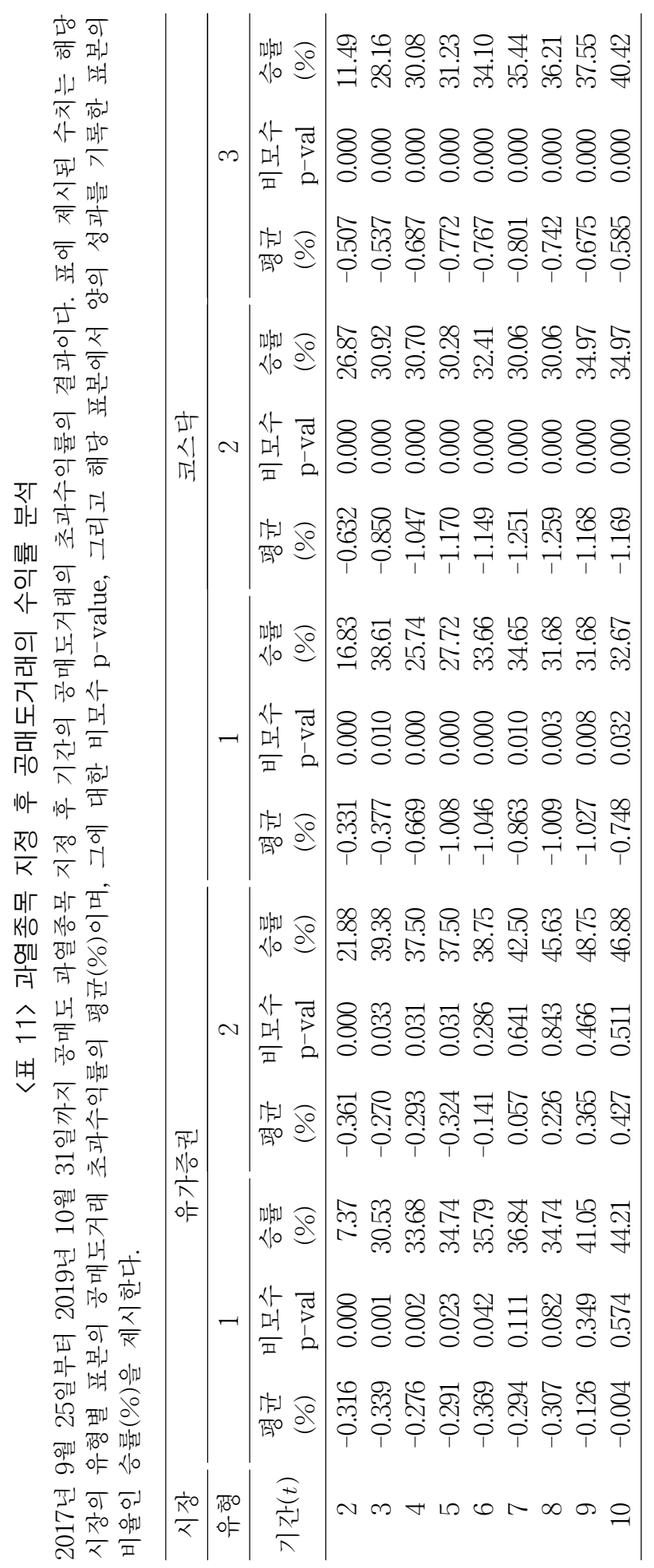


것이다. 본 연구의 표본기간에서는 증권거래세율이 2019 년 6월 3일부터 $0.05 \%$ 포인트 인하되어 이를 반영하였으며, 매매수수료율은 Kim and Woo(2019)의 연구에서 사용된 수수료율인 $0.01 \%$ 를 적용했다. 18$)$

$$
\operatorname{ssr}_{t}=\frac{\left(\text { avgssprc }_{2}-\operatorname{avgprc}_{t}\right)-\left(\operatorname{avgsspr}_{2}+\operatorname{avgprc}_{t}\right) \times \text { fee }^{-\operatorname{avgssprc}_{2} \times \operatorname{tax}}}{\operatorname{avgsprc}_{2}}-r_{m, t}
$$

여기에서 $t=2 \sim 10$

$s s r$ : 공매도 투자수익률

avgssprc: 공매도거래량가중평균가격

avgprc: 거래량가중평균가격

$t a x$ : 증권거래세율, $f e e$ : 매매수수료율

$r_{m}:$ 시장수익률(코스피수익률, 코스닥수익률)

유가증권시장에서 유형 1 의 지정 종목은 10 일까지 모든 거래일에서 음의 성과를 보였으며, 특히 6 일까지 비모수검정에서 $5 \%$ 수준에서 유의적인 손실을 기록했다. 유형 2 의 지정 종목도 6 일까지의 매 거래일에서 음의 성과로 나타났으며, 7 일부터는 양의 초과수익률로 전환되었으나 승률은 $50 \%$ 미만이며 비모수 검정 결과에서도 비유의적이다. 코스닥시장에서도 모든 유형에서 10 일까지의 모든 거래일동안 음의 초과수익률은 $5 \%$ 와 $1 \%$ 수준에서 유의적으로 나타났다. 이와 같은 결과는 공매도 과열종목 지정 해제 직후 공매도를 추종하는 전략으로는 단기적으로 이익을 실현할 수 없음을 제시한다.

\subsection{3 과열종목 지정 전·후 기간 악재성 공시 발표 빈도}

본 절에서는 과열종목 지정 전·후 기간에 발표된 악재성 공시 빈도를 분석하여 공매도 과열이 불공정거래로 인한 결과인지를 분석한다. Kim and Woo(2019)은 불공정거래의 개연성이 있는 매도거래는 향후 주가 하락을 야기하는 악재성 내용 공시 전에 내부정보로 취득하여 공매도를 하는 경우로 설명한다. 만일 내부자 또는 내부자로부터 미공개 중요정보를 수취한 거래자가 공매도를 한 다음, 악재성 공시 발표 후에 하락한 주가로 재매수하는 공매도 전략을 사용하는 기회적 내부자(opportunistic insider)는 평소와 다른 규모의 공매도 수량을 제출할 것이다. 아울러, 악재성 공시 후에 주가가 하락하는 추세를 따르는 추세 추종적 공매도의 출현도 수반된다. 따라서 과열 종목 지정 전의 공매도 거래가 이러한 불공정거래에 해당하는 공매도거나 추세 추종적 공매도라면, 과열 종목 지정 전에 악재성 공시 발표가 집중될 것이다.

<표 12>는 표본이 지정된 전·후 20일 기간동안 해당 종목에 대한 악재성 공시가 발표된 빈도를 제시한다. 표에 제시된 값은 해당 유형에 속하는 표본 종목에 대해 악재성 뉴스가 사건 기간동안 공시된 건수의 평균치이며 괄호안의 값은 사건기간에 공시가 발생한 거래일의 빈도이다.

18) 2019년 6월 3일부터 유가증권시장 종목에 대해서 증권거래세율은 $0.15 \%$ 에서 $0.10 \%$ 으로 인하 되었으며, 코스닥시장 종목에 대해서는 $0.30 \%$ 에서 $0.25 \%$ 로 인하되었다. 
The Effect of KRX Halts on Overheated Short-selling Stocks

악재성 정보는 $\mathrm{Kim}$ and $\mathrm{WoO}(2019)$ 의 연구에서 제시된 악재성 뉴스 공시를 지정한 유형과 같이 유상증자 및 감자, 최대주주변경, 손익구조변경, 단일판매공급해지가 발생한 종목으로 정했다. 2017년 9월 25일부터 2019년 10월 31일까지 네 종류의 악재성 공시가 발표된 빈도는 총 10,622 건이었으며, 공시 종류별로 보면 유상증자 및 감자(3,609건), 최대주주변경(2,190건), 손익구조변경(4,664건), 단일판매공급해지(159건)으로 분포되었다.

유가증권시장의 유형 1 에서 표본으로 지정 되기 전 20일간 악재성 내용이 공시된 거래일은 11 일이었으며, 거래일의 평균 공시건수는 2 건에 불과했다. 지정 후 20 일 간 악재성 내용이 공시된 거래일은 13 일로 지정 전 기간의 평균 공시건수인 1.46 건과 통계적으로 유의적인 차이가 없었다. 유가증권시장의 유형 2 에서도 표본 지정 전 20일 기간과 지정 후 20 일 기간내 악재성 내용이 공시된 평균 발표 빈도는 각각 1.80 건과 2.35 건으로 역시 유의적인 차이는 없었다. 코스닥의 각 유형도 2 유형과 3 유형에서 지정 후 기간의 평균 빈도가 증가했지만 통계적으로 유의적인 차이는 발견되지 않았다. 즉, 과열종목 지정 전·후기간의 악재성 공시가 균등하게 발표되는 경향을 보면 악재성 공시와 관련된 종목과 과열종목 지정 종목간의 유의적인 관련성은 발견할 수 없었다.

\section{〈표 12〉 과열 종목 지정 전 · 후 악재성 공시 빈도 비교}

2017년 9월 25일부터 2019년 10월 31일까지 공매도 과열종목 지정 전 기간(-20,0)과 지정 후 기간 $(1,20)$ 에 해당 종목의 악재성 공시가 발표된 평균 빈도이다. 개별 표본에 대해 지정일 기준 전·후 기간내 거래일에 발표된 악재성 공시 빈도를 합산한 다음, 기간별로 평균을 계산했으며 괄호안의 값은 공시가 발표된 거래일수이다. 차이 검정에서 각괄호안의 값은 비모수검정의 $\mathrm{p}^{-}$value이다.

\begin{tabular}{ccccc}
\hline \multirow{2}{*}{ 시장구분 } & 지정 유형 & $\begin{array}{c}\text { 지정 전 기간 } \\
\text { (pre period) }\end{array}$ & $\begin{array}{c}\text { 지정 후 기간 } \\
\text { (post period) }\end{array}$ & $\begin{array}{r}\text { 차이 검정 } \\
\text { (post-pre) }\end{array}$ \\
\hline \multirow{3}{*}{ 유가증권 } & 1 & $2.00(11)$ & $1.46(13)$ & $-0.54[0.26]$ \\
& 2 & $1.80(15)$ & $2.35(17)$ & $0.55[0.21]$ \\
\cline { 2 - 5 } & 전체 & $2.58(19)$ & $3.10(19)$ & $0.52[0.14]$ \\
\hline \multirow{3}{*}{ 코스닥 } & 1 & $1.82(11)$ & $1.67(6)$ & $-0.15[0.78]$ \\
& 2 & $10.86(21)$ & $11.95(20)$ & $1.09[0.20]$ \\
& 3 & $3.75(20)$ & $4.10(19)$ & $0.35[0.48]$ \\
\cline { 2 - 5 } & 전체 & $15.38(21)$ & $16.35(20)$ & $0.97[0.33]$ \\
\hline
\end{tabular}

\section{4. 결론}

공매도 과열종목 지정제도는 비정상적으로 공매도가 급증하고 가격이 급락한 종목을 공매도 과열종목으로 지정하여 단기과열 현상을 완화하고 해당 종목에 대해 투자자의 주의를 환기시키기 위한 시장경보제도의 일종이다. 본 연구는 2017년 3월에 최초로 도입된 공매도 과열종목 지정제도가 변경된 2017년 9월부터 2019년 10월까지의 기간동안 과열종목으로 지정된 표본을 대상으로 이 제도의 기능을 실효성을 실증적으로 평가했다. 본 연구의 결과를 요약하면 다음과 같다. 
시장과 유형별로 과열 종목 지정 전 기간의 수익률은 지정 후 기간에도 지정일 수준의 주가변동에 후속하는 추가적인 주가변동은 없는 것으로 분석되었다. 즉, 주가가 급락하여 과열 종목으로 지정된 유형은 지정 후 기간에 하락하는 추세가 현저히 제한되었으며, 지정일에 주가가 상승한 종목의 유형의 표본들에서는 지정 후 기간에도 추가적 상승 없이 진정되는 행태를 보였다. 이는 공매도 과열 거래에 내포된 투기거래에 대한 주의를 환기하여 추가주가 급락과 추종매매를 억제하여 급격한 가격변동을 완화하는 기능을 수행하는 과열 종목 지정 제도의 본질적 목적에 부합한다고 평가된다. 또한 주가 변동성도 지정일에만 급등했으나, 지정 후 기간의 변동성은 지정 전 기간의 수치와 유의적인 차이를 발견할 수 없었다. 이는 공매도의 과열 종목 지정이라는 정보 내용이 시장의 투자자들에게 공매도 과열에 대한 주의를 환기시켜 정보비대칭을 해소한 결과로 해석할 수 있다 공매도 행태를 측정하는 지표인 공매도거래비율의 과열 종목 지정 후의 수치는 지정 전 기간과 통계적으로 유의적인 차이는 발견되지 않거나, 감소하는 결과가 도출되었다. 이같은 결과는 과열종목 지정 전 이상 공매도로 의심되는 공매도를 매매중단으로 차단하여 사후적으로 발생가능한 불공정거래 행위를 완화하는 효과에 부합한다고 평가된다.

이같은 실증분석 결과는 현행 공매도 과열종목 지정제도는 투자자의 주의를 환기하여 시장 상황을 판단할 수 있는 기회를 부여하며, 주가변동을 진정시키는 시장 건전화 기능에 대한 정보 효과가 존재함을 시사한다. 그러나, 과열종목 지정제도의 추가적인 기능은 바로 불공정거래 의심이 있는 이상거래를 탐지할 수 있는 기능이다. 본 연구에서는 공매도 과열종목 지정제도를 표본에 한정하여 사후적 효과를 평가했지만, 과열종목 지정을 유발한 공매도가 불공정거래의 기반이 되는 내부 사적정보를 이용한 공매도인지는 확인하지 못한 점은 한계라 할 수 있다. 이에 대해서는 추가 연구가 요망된다. 
The Effect of KRX Halts on Overheated Short-selling Stocks

\section{References}

Battalio, R., and P. Schultz, 2011, Regulatory Uncertainty and Market Liquidity: The 2008 Short Sale Ban's Impact on Equity Option Markets, Journal of Finance, Vol. 66 (6), pp. 2014-2053.

Beber, A., and M. Pagano, 2013, Short-selling Bans around the World: Evidence from the 2007-09 Crisis, Journal of Finance, Vol. 68 (1), pp. 343-381.

Boehmer, E., C. Jones, and X. Zhang, 2013, Shackling Short Sellers: The 2008 Shorting Ban, Review of Financial Studies, Vol. 26 (6), pp. 1363-1400.

Choe, H., and H. J. Lee., 2012, Short Sales Restriction versus Short Sales Prohibition : Different Effects on Market Efficiency, Asian Review of Financial Research, Vol. 25 (2), pp. 161-202.

Financial Services Commission, Financial Supervisory Service and Korea Exchange, 2017, Measures to Improve Short-selling System and Restrictions, Press Release. (https: //www.fsc.go.kr/info/ntc_news_view.jsp?menu=7210100\&bbsid=BBS0030\&no=32006)

Grundy, B. D., B. Lim, and P. Verwijmeren, 2012, Do Option Markets Undo Restrictions on Short Sales? Evidence from the 2008 Short-sale Ban, Journal of Financial Economics, Vol. 106 (2), pp. 331-348.

Kang, S. H., 2017, Effect and Implications of Overheated Short-selling Stocks Designation, Issue Paper 17-09, Korea Capital Market Institute. (https://www.kcmi.re.kr/report/ report_view?report_no $=860 \&$ s_report_subject $=002002001009 \&$ s_report_type $=00200200$ 2013\&pg=7)

Kim, J. H., and M. C. Woo, 2019, Possible Unfair Trades Using Short-Sale, Korean Journal of Financial Studies, Vol. 48 (1), pp. 105-128.

Kim, J. S., and S. W. Seo, 2015, The Effect of Short Sale Ban on the Relation between Disagreement and Stock Returns, Korean Journal of Futures and Options, Vol. 23, (2) pp. $155-182$.

Kolasinski, A. C., A. Reed, and J. R. Thornock, 2013, Can Short Restrictions Actually Increase Informed Short Selling?, Financial Management, Vol. 42 (2), pp. 155-181.

Lee, W. B., and J. W. Park, 2016, A Study on the Effect of Individual Trading Halts: Case of 'The Measures to Ease Temporary Overheat' in KRX, Financial Stability Studies, Vol. 17 (2), pp. 73-111.

Marsh, I. W., and R. Payne, 2012, Banning Short-sales and Market Quality: The UK's experience, Journal of Banking and Finance, Vol. 36 (7), pp. 1975-1986.

Saffi, P. A. and K. Sigurdsson, 2010, Price Efficiency and Short-selling, Review of Financial Studies, Vol. 24 (3), pp. 821-852.

Wang, S. F., K. H. Lee, and M. C. Woo., 2017, Do Individual Short-sellers Make Money? Evidence from Korea, Journal of Banking and Finance, Vol. 79, pp. 159-172. 